\title{
The value-added tax and growth: design matters
}

\author{
Santiago Acosta-Ormaechea ${ }^{1} \cdot$ Atsuyoshi Morozumi $^{2}$ (D)
}

Accepted: 10 June 2021

(c) The Author(s) 2021

\begin{abstract}
Previous research has shown that changes in the composition of tax revenue affect long-run growth. However, little is yet known about whether the way tax revenue is raised matters for growth. This paper examines whether, in the context of OECD countries, a revenue-neutral increase in the value-added tax (VAT), offset by a fall in income taxes, may have different effects on long-run growth depending on how the VAT is raised. We show that a revenue-neutral rise in the VAT promotes growth when it is raised through a rise in $C$-efficiency, while it does not when it is raised through a rise in the standard VAT rate, the rate applied to the largest portion of taxed consumption. C-efficiency measures the departure of the VAT from a perfectly enforced tax levied at a single rate on all consumption, which in advanced economies is largely due to the VAT that is not levied because of exemptions and reduced rates. Thus, our results suggest that an increase in C-efficiency, possibly reflecting the broadening of the VAT base through fewer exemptions and a more uniform rate structure with fewer reduced rates, promotes growth more than a rise in the standard rate.
\end{abstract}

Keywords Economic growth - Tax composition - VAT $\cdot$ Standard rate $\cdot$ Base broadening

JEL Classification E62 $\cdot \mathrm{H} 20 \cdot \mathrm{O} 47$

Atsuyoshi Morozumi

Atsuyoshi.Morozumi@nottingham.ac.uk

Santiago Acosta-Ormaechea

SAcostaOrmaechea@imf.org

1 International Monetary Fund, 700 19th Street N.W., Washington DC 20431, USA

2 School of Economics \& CFCM, University of Nottingham, University Park,

Nottingham NG7 2RD, UK 


\section{Introduction}

Previous empirical literature has shown that tax composition matters for long-run growth. For instance, it has been found that a revenue-neutral increase in consumption taxes, offset by a fall in income taxes, promotes growth in the long run (e.g., Arnold et al. (2011) and Acosta-Ormaechea et al. (2019)). However, this literature has been largely silent on the possible relevance of the way in which the composition of taxes is changed. In particular, little is known about whether the growth effect of a compositional change of taxes depends on whether a tax is raised through a rate increase or through a base broadening. This paper aims to shed light on this issue highlighting how the value-added tax (VAT), a type of consumption tax which has become increasingly popular over the last few decades, is raised in the context of a revenue-neutral reallocation with income taxes. ${ }^{1}$

To begin with, why might it matter for growth how the VAT is raised? This is essentially because certain design features of the VAT such as exemptions and differentiated rates might induce inefficient allocation of resources. This is the case even though theory often suggests that consumption taxes, in general, might not distort optimizing agents' investment decisions directly unlike income taxes. ${ }^{2}$ Exemptions mean that no tax is charged on sales, but a VAT charged on inputs is not refunded/ credited, whereas a pure VAT taxes all sales (including both wholesale and retail) and allows registered businesses to reclaim the tax charged on their inputs. ${ }^{3}$ Thus, based on the view that exemptions distort firms' input choices and create an element of production tax (Crawford et al. 2010; Keen 2013, and Cnossen 2020), they are likely to compromise the efficient allocation of resources, possibly having an adverse growth effect. Further, differentiated rates, where reduced rates are applied to selected goods and services, may also have a negative growth effect. This is associated with the view that they increase administration costs (Ebrill et al. 2001) and distort consumer choice through their effects on relative prices (Mirrlees et al. 2011). Taken together, a VAT revenue increase through broadening the base with fewer exemptions and/or achieving a more uniform rate structure with fewer reduced rates may be more growth promoting than a revenue increase through a rise in the standard rate, the rate applied to the largest portion of taxed consumption, because the latter increase is likely to forgo the efficiency gains.

To consider the relevance of the form in which the VAT is raised formally, this paper decomposes the VAT following Keen (2013). Specifically, we decompose the VAT revenue $(V)$ as a share of total tax revenue $(T)$ as:

\footnotetext{
${ }^{1}$ As of November 1, 2018, 168 countries and territories worldwide have adopted the VAT, including all the OECD countries with the only exception of the USA (OECD 2018).

2 Theory does not always predict that consumption taxes are non-distortionary. For example, the theoretical model of Mendoza et al. (1997) suggests that consumption taxes can have a negative growth effect by distorting agents' investment decisions through the effect on their labor supply.

${ }^{3}$ Note that there is a distinction between exemptions and zero-rated goods (on which VAT can be reclaimed on inputs).
} 


$$
\frac{V}{T}=\mathrm{rec}
$$

where $r$ is the VAT standard rate; $e(\equiv V /(r C))$ is C-efficiency, the ratio of VAT revenue to the product of the VAT standard rate and final consumption (excluding VAT revenue collection), $C$; and $c(\equiv C / T)$ is the ratio of final consumption to total tax revenue. Here, $\mathrm{C}$-efficiency measures the departure of the VAT from a perfectly enforced tax levied at a single rate on all consumption. It takes a value lower than one, when exemptions and reduced rates apply to some goods and services, and/or taxpayers' compliance is limited (Ebrill et al. 2001 and IMF 2011). ${ }^{4}$ In this regard, Keen (2013) suggests that, in advanced economies, the deviation of C-efficiency from the value of one arises primarily because of the VAT that is not levied due to exemptions and reduced rates (the policy gap), rather than the issues of taxpayers' imperfect compliance (the compliance gap). The dominance of the policy gap over the compliance gap is echoed for Netherlands by Bettendorf and Cnossen (2015), who provide a detailed account of C-efficiency for the country. Further, Ueda (2017) shows that, in the context of EU member countries and Japan, cumulative changes in C-efficiency over the 2000-14 period are largely driven by cumulative changes in policy gaps. The present paper thus investigates the growth effect of C-efficiency relative to that of the standard rate in OECD countries, to shed light on the relevance of VAT policy design to growth.

Our key findings are the following. Using a dataset for 21 OECD countries over the 1970-2018 period, we show that a rise in the VAT, offset by a fall in income taxes, promotes long-run growth only if the VAT revenue is raised through C-efficiency, but not if it is raised through the VAT standard rate. This result holds regardless of whether a rise in VAT revenue is offset by a fall in personal or corporate income taxes. The implication is thus that the design of how the VAT is raised matters for growth in the context of a tax reallocation between the VAT and income taxes. ${ }^{5}$ Further, we show that, for a given VAT revenue, a rise in C-efficiency, offset by a fall in the standard rate, also fosters growth. This result demonstrates the general relevance of VAT design to growth, beyond the context of the specific reallocation between the VAT and income taxes. The possible interpretation is that, in the context of OECD countries, an increase in C-efficiency, reflecting (at least partly) the VAT base broadening through fewer exemptions and a more uniform rate structure with fewer reduced rates, promotes growth more than an increase in the standard rate.

We acknowledge from the outset, however, that although this paper provides extensive evidence for the relevance of VAT design to growth, there are at least two important limitations. The first one is the absence of an analysis of income

\footnotetext{
${ }^{4}$ To explain, businesses offset the VAT they have been charged on their purchases (inputs) against the liability on their sales (output). Therefore, if a uniform VAT rate is applied to all goods, and if taxes are enforced perfectly, the VAT revenue equals the uniform rate of the (tax-exclusive) value of the sales made to final consumers, i.e., C-efficiency takes the value of one.

${ }^{5}$ Although a similar decomposition exercise can potentially be attempted to income tax revenue, our focus here is the decomposition of the VAT.
} 
distribution. That is, even if VAT exemptions and rate differentiation might have an adverse impact on growth through inefficient resource allocation, they could have a positive impact on income distribution. The use of reduced rates, in particular, might benefit the poor relatively more than the rich, implying that it is important to consider the impact on income distribution as well to have a more balanced view on the overall VAT design impact. The second limitation is that variations in C-efficiency are likely to reflect much more than variations in the breadth of the VAT base and the degree of rate differentiation caused directly by VAT policy reforms. This is illustrated clearly by the fact that C-efficiency exhibits pro-cyclicality (as elaborated below). Thus, although we show that our results appear to be robust to the endogeneity concerns associated with business cycle fluctuations, the growth effects of C-efficiency cannot be interpreted narrowly as the effects of policies that impact on the breadth of VAT base and/or the degree of differentiated rates.

The rest of the paper is organized as follows. Section 2 reviews the related literature. Section 3 explains the empirical methodology, and Sect. 4 describes the data. Section 5 presents and interprets results, and Sect. 6 offers concluding remarks.

\section{Related literature}

This paper is related to the empirical works that assess the growth effects of different tax revenue categories. The relation is particularly close to those papers that take account of the government budget constraint (GBC) as a "closed system", whereby a change in one fiscal component must be balanced by an equal and opposite change in other component(s) to meet the GBC. ${ }^{6}$ For instance, using a panel of 21 OECD countries over 34 years, Arnold et al. (2011) find that in the context of revenue-neutral tax reallocations, a rise in consumption taxes, offset by a fall in income taxes, promotes growth. While Xing (2012) suggests that results might not be fully robust, Acosta-Ormaechea et al. (2019) find that consumption taxes are indeed more growth friendly than income taxes even in a broader sample of 70 countries over 40 years. Gemmell et al. (2011) categorize taxes into distortionary and non-distortionary ones based on whether they directly affect investment decisions and show, in the context of 17 OECD countries, that changes in those taxes have different growth effects when the budget deficit is assumed to finance them. ${ }^{7}$ However, those papers do not examine the role of the VAT per se, and, more importantly, the relevance to growth of how taxes are collected is left unanswered.

Several empirical papers have investigated the effect of the VAT on macroeconomic aggregates. For example, Alm and El-Ganainy (2013) show, in a panel of 15 EU countries over the 1961-2005 period, that increases in the VAT rate could

\footnotetext{
${ }^{6}$ See Kneller et al. (1999) for a seminal discussion on the relevance of GBC to growth regressions. For an extensive review of the literature on taxation and growth, see Kneller and Misch (2011).

7 To elaborate, they show that a rise in distortionary taxes (combined with other taxes such as taxation on international trade), financed by a fall in the budget deficit, reduces long-run growth, while a rise in non-distortionary taxes promotes growth. They categorize taxation on domestic goods and services as non-distortionary taxes.
} 
lead to both short- and long-run reductions in aggregate consumption. Smart and Bird (2009), highlighting reforms undergone in some (but not all) Canadian provinces where retail sales taxes are replaced by value-added taxes, show that this tax substitution increased business investment. Further, Riera-Crichton et al. (2016), assembling a quarterly VAT dataset for 14 industrial countries, investigate the output effect of VAT rate changes. ${ }^{8}$ In the meantime, Adhikari (2020) emphasizes that the VAT adoption has a different output effect depending on the income level of the country, citing some distinctive features of developing countries such as the prevalence of tax evasion.

Turning to the effect of the VAT on economic growth, Ferede and Dahlby (2012) show that, in Canada, a switch to a provincial VAT from a provincial retail sales tax promotes growth through its positive effect on investment. Ufier (2014) finds that, after taking account of a selection problem due to an endogenous decision to adopt the VAT, its adoption is associated with increases in investment, and less robustly with increases in growth. Next, in perhaps the most closely related work to ours, Institute for Fiscal Studies (2011) argue that the long-run effects of the VAT and its components, such as the standard rate and C-efficiency, on either aggregate consumption or GDP growth are negligible in the sample of 40 countries. What is distinct in our work is that we estimate the growth effects of the different VAT components by explicitly incorporating the GBC (i.e., specifying their compensating elements within the budget constraint), particularly in the context of a tax reallocation with income taxes. ${ }^{9}$

Various papers also examine how C-efficiency evolves both in the short run and long run. Regarding the short-run fluctuation, Sancak et al. (2010), using a broad sample of advanced and developing countries, report that C-efficiency is pro-cyclical. They find that shifts in consumption patterns toward goods and services with reduced VAT rates and higher tax evasion could explain the observed reductions in C-efficiency during economic contractions. Further, Ueda (2017), using a panel of EU countries and Japan from 2000 to 2014, explores the business cycle effects on C-efficiency by decomposing the latter into compliance and policy gaps. Turning to the structural determinants of C-efficiency changes, Tanzi and Davoodi (2000), using a sample of 83 countries, show that countries with higher corruption tend to have lower C-efficiency. Further, Aizenman and Jinjarak (2008) find, using a panel of 44 countries, that lower durability of political regimes reduces C-efficiency. ${ }^{10}$ While those studies shed light on the short- and long-run determinants of C-efficiency, our focus is instead on the long-run consequences of a change in C-efficiency (alongside a change in the VAT standard rate) on economic growth.

\footnotetext{
${ }^{8}$ Dabla-Norris and Lima (2018) also investigate the macroeconomic effects (including output effect), separating effects of tax rate and base changes. Their result on the output effect of VAT rate indicates that an increase in a VAT rate has a negative and statistically significant impact on output in the short run.

9 In contrast, Institute for Fiscal Studies (2011) do not specify which fiscal element is adjusted when each VAT component changes.

${ }^{10}$ De Mello (2009) point out other structural factors associated with C-efficiency, such as the efficiency of tax administration and the country's governance indicators.
} 


\section{Econometric methodology}

Following recent empirical works on fiscal policy and growth (e.g., Arnold et al. 2011; Gemmell et al. 2011, 2014, 2016, and Acosta-Ormaechea et al. 2019), we use the pooled mean group (PMG) methodology of Pesaran et al. (1999). This method allows us to estimate the long-run growth effects of the VAT in a cross-country setting, while allowing independent dynamics for each country. In the PMG method, the long-run relationship between the relevant variables and growth is constrained to be equal across countries. Meanwhile, in the alternative mean group (MG) method of Pesaran and Smith (1995), which allows for both short- and long-run parameter heterogeneity, separate autoregressive distributed lag (ARDL) models are estimated for each country, and the average of each parameter across all countries is then computed. If homogeneity of the long-run response is not rejected by a Hausman test, the PMG estimator is preferred due to its higher efficiency relative to the MG estimator. In what follows, while we follow the PMG approach, we routinely test the assumption of long-run homogeneity. The PMG method is useful in the current context, because it provides a flexible framework to differentiate the 'permanent (longrun)' from 'transitory (short-run)' growth effect of tax composition change. That is, it accommodates the possibility that some tax reallocations may only have level effects on output (i.e., short-run growth effects), while others may have long-run growth effects.

Formally, our baseline equation takes the following form:

$$
g_{i, t}=\mathbf{f}_{i, t}^{\prime} \delta_{0 i}+\mathbf{f}_{i, t-1}^{\prime} \delta_{1 i}+\lambda_{i} g_{i, t-1}+\sum_{j=1}^{n} \gamma_{0 i, j} z_{i, j, t}+\sum_{j=1}^{n} \gamma_{1 i, j} z_{i, j, t-1}+\epsilon_{i, t}
$$

where $g_{i, t}$ is the growth rate of annual real GDP per capita in country $i$ in year $t$. $\mathbf{f}_{i, t}^{\prime}$ is a vector of tax variables (elaborated below); $z_{i, j, t}$ are control variables, which contain the investment rate (i.e., the share of gross fixed capital formation in GDP) and employment growth. We also control routinely for the share of total government consumption in GDP. The equation takes an ARDL structure, where both dependent and independent variables are included in the right hand side with a lag of order 1. We restrict the number of lags to be 1 in our baseline analysis, because, with the use of MG and PMG estimators, and with our objective of investigating the relevance of VAT components (using Eq. 1), a degree of freedom problem can be reached soon. ${ }^{11}$ In what follows, Eq. 2 will be re-parameterized into an 'error correcting' form, which allows us to estimate long-run growth effect of taxation separately from short-run (or level) effect. As mentioned, the PMG method imposes homogeneity of long-run parameter, whereas the MG method allows for both short- and long-run parameter heterogeneity.

11 Robustness checks below explore expansion of the lag structure of the ARDL model. 


\subsection{Without considering how VAT revenue is raised}

Our aim is to consider whether it matters for growth how VAT revenue is raised in the context of tax reallocations with income taxes. To start, however, we consider the growth effects of the VAT without considering how it is raised, akin to the conventional approach taken in the empirical literature on taxation and growth.

First, we specify that the contemporaneous growth effect of tax variables, $\mathbf{f}_{i, t}^{\prime} \delta_{0 i}$ (in Eq. 2), takes the form of:

$$
\mathbf{f}_{i, t}^{\prime} \delta_{0 i}=\delta_{0 i}^{T} t_{-} \operatorname{tax}_{i, t}+\sum_{j=1}^{m} \delta_{0 i, j}^{S} s_{i, j, t},
$$

where $t_{-} \operatorname{tax}_{i, t}$ is the ratio of total tax revenue to GDP, and $s_{i, j, t}$ is the share of tax item $\mathrm{j}$ in total tax revenue, which comprises $m$ different tax types. Here, notice that since $\sum_{j=1}^{m} s_{i, j, t}=1$ by construction, we omit one tax item to avoid perfect multicollinearity. To be specific, we assume that there are three tax shares $(m=3)$ : VAT (denoted by $\left.s_{i, V, t}\right)$, income taxes $\left(s_{i, I, t}\right)$, and the other taxes $\left(s_{i, O, t}\right)$. Then, if we omit the income tax share, $s_{i, I, t}$, from Eq. 3, we have:

$$
\mathbf{f}_{i, t}^{\prime} \delta_{0 i}=\delta_{0 i}^{T} t_{-} \operatorname{tax}_{i, t}+\left(\delta_{0 i, V}^{S}-\delta_{0 i, I}^{S}\right) s_{i, V, t}+\left(\delta_{0 i, O}^{S}-\delta_{0 i, I}^{S}\right) s_{i, O, t}+\delta_{0 i, I}^{S} .
$$

Here, a coefficient on the VAT share, $\delta_{0 i, V}^{S}-\delta_{0 i, I}^{S}$, measures the contemporaneous effect of a revenue-neutral increase in the VAT on growth, particularly when it is offset by a fall in income taxes. The lagged effect of taxation on growth, $\mathbf{f}_{i, t-1}^{\prime} \delta_{1 i}$, can be defined likewise.

Next, the long-run growth effect of a rise in the VAT (offset by income taxes) can be estimated after re-parameterizing Eq. 2 in an error correction form:

$$
\begin{aligned}
\triangle g_{i, t}= & \phi_{i}\left(g_{i, t-1}-\theta_{i}^{T} t_{-} \operatorname{tax}_{i, t-1}-\left(\theta_{i, V}^{S}-\theta_{i, I}^{S}\right) s_{i, V, t-1}-\left(\theta_{i, O}^{S}-\theta_{i, I}^{S}\right) s_{i, O, t-1}-\sum_{j=1}^{n} \eta_{i, j} z_{i, j, t-1}\right) \\
& + \text { SR_dynamics }+\delta_{0 i, I}^{S}+\delta_{1 i, I}^{S}+\epsilon_{i, t},
\end{aligned}
$$

where $\triangle g_{i, t}$ denotes the first-difference of the growth rate, and $\phi_{i}=-\left(1-\lambda_{i}\right)$ represents the error-correction speed of adjustment. In this context, if the long-run coefficient on the VAT share, $\theta_{i, V}^{S}-\theta_{i, I}^{S}$, where $\theta_{i, V}^{S}=\left(\delta_{0 i, V}^{S}+\delta_{1 i, V}^{S}\right) /\left(1-\lambda_{i}\right)$ and $\theta_{i, I}^{S}=\left(\delta_{0 i, I}^{S}+\delta_{1, I}^{S}\right) /\left(1-\lambda_{i}\right)$, is positive, it means that an increase in VAT revenue, financed by a fall in income taxes, is associated with higher long-run growth. Meanwhile, $S R \_$dynamics in Eq. 5 captures the short-run dynamics toward the long-run equilibrium (i.e., level effects), which can be elaborated as:

$$
\begin{aligned}
\text { SR_dynamics }=_{-} & \delta_{0 i}^{T} \triangle t_{-} \operatorname{tax}_{i, t}+\left(\delta_{0 i, V}^{S}-\delta_{0 i, I}^{S}\right) \triangle s_{i, V, t} \\
& +\left(\delta_{0 i, O}^{S}-\delta_{0 i, I}^{S}\right) \triangle s_{i, O, t}+\sum_{j=1}^{n} \gamma_{0 i, j} \triangle z_{i, j, t} .
\end{aligned}
$$


Eq. 5 (together with Eq. 6) is the MG version of our regression equation, whereas in the PMG version, homogeneity of the long-run parameters is imposed (e.g., $\theta_{i}^{T}$ becomes $\theta^{T}$ ). In what follows, our focus is primarily on the long-run effect of taxation on growth.

\subsection{Highlighting how VAT revenue is raised}

To examine how the way VAT revenue is raised may matter for long-run growth, we utilize the aforementioned decomposition method of VAT revenue share (cf. Eq. 1):

$$
s_{i, V, t}\left(\equiv V_{i, t} / T_{i, t}\right)=r_{i, t} e_{i, t} c_{i, t},
$$

where $V_{i, t}\left(T_{i, t}\right)$ is VAT (total tax) revenue in country $i$ in year $t$. The right hand side consists of the three VAT components: $r_{i, t}$ is the VAT standard rate; $e_{i, t}\left(\equiv V_{i, t} /\left(r_{i, t} C_{i, t}\right)\right)$ is C-efficiency; and $c_{i, t}\left(\equiv C_{i, t} / T_{i, t}\right)$ is the ratio of final consumption (excluding VAT revenue collection) to total tax revenue.

To proceed, we first add the log of the three VAT components to the contemporaneous effect of taxes on growth (cf. Eq. 4):

$$
\begin{aligned}
\mathbf{f}_{i, t}^{\prime} \delta_{0 i} & =\delta_{0 i}^{T} t_{-} \operatorname{tax}_{i, t}+\left(\delta_{0 i, V}^{S}-\delta_{0 i, I}^{S}\right) s_{i, V, t}+\left(\delta_{0 i, O}^{S}-\delta_{0 i, I}^{S}\right) s_{i, O, t} \\
& +\delta_{0 i}^{R} \ln (r)_{i, t}+\delta_{0 i}^{E} \ln (e)_{i, t}+\delta_{0 i}^{C} \ln (c)_{i, t}+\delta_{0 i, I}^{S} .
\end{aligned}
$$

Next, because Eq. 8 contains the VAT revenue share and all the three components simultaneously, one component needs to be omitted (otherwise, the coefficients cannot be interpreted). To do this, we utilize the fact that a log linear approximation to the VAT revenue share yields

$$
s_{i, V, t} \approx a+b\left(\ln (r)_{i, t}+\ln (e)_{i, t}+\ln (c)_{i, t}\right),
$$

where $a \equiv x-x \ln (x)$ and $b \equiv x \cdot \ln (x)$ is the point around which the log of the VAT revenue share is approximated. ${ }^{12}$ If we use Eq. 9 to omit (the $\log$ of) standard rate from Eq. 8, we obtain:

$$
\begin{aligned}
\mathbf{f}_{i, t}^{\prime} \delta_{0 i} & =\delta_{0 i}^{T} t_{-} \operatorname{tax}_{i, t}+\left(\delta_{0 i, V}^{S}+\delta_{0 i}^{R} / b-\delta_{0 i, I}^{S}\right) s_{i, V, t}+\left(\delta_{0 i, O}^{S}-\delta_{0 i, I}^{S}\right) s_{i, O, t} \\
& +\left(\delta_{0 i}^{E}-\delta_{0 i}^{R}\right) \ln (e)_{i, t}+\left(\delta_{0 i}^{C}-\delta_{0 i}^{R}\right) \ln (c)_{i, t}+\delta_{0 i, I}^{S}-(a / b) \delta_{0 i}^{R} .
\end{aligned}
$$

Importantly, the coefficient on the VAT share, $\delta_{0 i, V}^{S}+\delta_{0 i}^{R} / b-\delta_{0 i, I}^{S}$ now captures the contemporaneous effect of a rise in the VAT, offset by a fall in income taxes, particularly when it is driven by an increase in the standard rate, the omitted VAT component. Meanwhile, the coefficient on the log of C-efficiency, $\delta_{0 i}^{E}-\delta_{0 i}^{R}$ measures the growth impact of a rise in C-efficiency, offset by a fall in the standard rate, for a given level of VAT revenue. The lagged effect of $\mathbf{f}_{i, t-1}^{\prime} \delta_{1 i}$ can be considered likewise.

Then, Eq. 2 can be re-parameterized in an error correction form as:

12 To explain, $\ln \left(s_{i, V, t}\right)$ is approximated as $\ln (x)+\left(s_{i, V, t}-x\right) / x$. Rewriting this yields Eq. 9 . 


$$
\begin{aligned}
\triangle g_{i, t}= & \phi_{i}\left(g_{i, t-1}-\theta_{i}^{T} t_{-} \operatorname{tax}_{i, t-1}-\left(\theta_{i, V}^{S}+\theta_{i}^{R} / b-\theta_{i, I}^{S}\right) s_{i, V, t-1}\right. \\
& -\left(\theta_{i, O}^{S}-\theta_{i, I}^{S}\right) s_{i, O, t-1}-\left(\theta_{i}^{E}-\theta_{i}^{R}\right) \ln (e)_{i, t-1}-\left(\theta_{i}^{C}-\theta_{i}^{R}\right) \ln (c)_{i, t-1} \\
& \left.-\sum_{j=1}^{n} \eta_{i, j} z_{i, j, t-1}\right)+\mathrm{SR} \_ \text {dynamics }+ \text { constant }+\epsilon_{i, t} .
\end{aligned}
$$

Here, the coefficient on the VAT share, $\theta_{i, V}^{S}+\theta_{i}^{R} / b-\theta_{i, I}^{S}$, captures the long-run effect of an increase in VAT revenue, offset by a fall in income taxes, when the rise in the VAT is solely taking place through an increase in the standard rate. ${ }^{13}$ Similarly, if we omit (the log of) C-efficiency from the explanatory variables, we can estimate instead the revenue-neutral long-run growth effect of a rise in the VAT driven only through a rise in C-efficiency. Last, the coefficient on C-efficiency, $\theta_{i}^{E}-\theta_{i}^{R}$, captures the long-run effect of a rise in C-efficiency, offset by a fall in the standard rate, for a given level of VAT revenue. As before, Eq. 11 is the MG version of our regression equation, while the PMG version imposes homogeneity of the long-run parameters (i.e., the long-run coefficients inside the large brackets in Eq. 11 do not depend on country $i$ ).

\section{Dataset}

We assemble an annual dataset covering 21 OECD countries during the 1970-2018 period. With 830 observations in total, the average observation available per country is about 40. To mitigate the issue of degrees of freedom, only countries with at least 25 annual successive observations are included. ${ }^{14}$ Tax revenue data are at the general government level from OECD's Revenue Statistics Database. Total taxes are calculated as the sum of consumption taxes (of which the VAT is a part); personal income taxes; corporate income taxes; property taxes; and social security contributions (which include taxes on payroll and workforce). ${ }^{15}$ Because the data are

\footnotetext{
13 Regarding the notation used here, $\theta_{i}^{R}$, for instance, is $\left(\delta_{0 i}^{R}+\delta_{1 i}^{R}\right) /\left(1-\lambda_{i}\right)$. All the long-run parameters are defined likewise. Also, for completeness, SR_dynamics $=\delta_{0 i}^{T} \triangle t_{-} t_{a x}+\left(\delta_{0 i, V}^{S}+\delta_{0 i}^{R} / b-\delta_{0 i, I}^{S}\right) \triangle$ $s_{i, V, t}+\left(\delta_{0 i, O}^{S}-\delta_{0 i, I}^{S}\right) \triangle s_{i, O, t}+\left(\delta_{0 i}^{E}-\delta_{0 i}^{R}\right) \triangle \ln (e)_{i, t}+\left(\delta_{0 i}^{C}-\delta_{0 i}^{R}\right) \triangle \ln (c)_{i, t}+\sum_{j=1}^{n} \gamma_{0 i, j} \triangle z_{i, j, t}, \quad$ and constant $=\delta_{0 i, I}^{S}+\delta_{1 i, I}^{S}-(a / b)\left(\delta_{0 i}^{R}+\delta_{1 i}^{R}\right)$.

14 The following is a list of countries covered, together with years in which VAT is introduced (figures in brackets). Austria (1973), Belgium (1971), Denmark (1967), France (1968), Germany (1968), Greece (1987), Hungary (1988), Iceland (1990), Ireland (1972), Italy (1973), Japan (1989), Korea (1977), Luxembourg (1970), Netherlands (1969), New Zealand (1986), Norway (1970), Portugal (1986), Spain (1986), Sweden (1969), Turkey (1985), and United Kingdom (1973). Differences in the timing of the VAT introduction render the dataset an unbalanced panel. To note, Canada is not included because the standard rates differ across provinces, and the USA does not have a VAT. Countries that are not included due to the threshold of 25 observations include Australia, for instance.

${ }^{15}$ Consumption taxes nest other taxes (than the VAT) such as sales tax and excises. While the VAT is a tax levied on the sale of goods and services by registered businesses not only to private consumers but also to other businesses, a sales tax only taxes sales to final consumers.
} 
annual, we adjust the VAT standard rate, which is set at different times within a year, by considering the month in which the rate is changed. Briefly, when the rate is changed in a given year, we take a weighted average of the rates prevalent before and after the change using the information on the month in which it occurred. ${ }^{16}$ Once the (adjusted) standard rates are obtained, C-efficiency can be calculated as the ratio of VAT revenue to the product of the standard rate and final consumption (as defined in the national accounts statistics, but excluding VAT revenue). Appendix A presents data sources.

Table 1 presents descriptive statistics for the 21 OECD countries during the sample period. The average annual growth rate of real GDP per capita is 2.1 percent. The size of total taxes, relative to GDP, is 35 percent on average, and the share of consumption taxes within total taxes accounts for 32.6 percent. The share of income taxes, against which we consider the growth effect of the different components of the VAT, is 35.1 percent of total taxes when personal income ( 26.8 percent) and corporate income taxes ( 8.3 percent) are combined. Property taxes account for a

Table 1 Descriptive statistics

\begin{tabular}{lllll}
\hline Variable & Mean & Std. Dev. & Min. & Max. \\
\hline Growth rate of real GDP pc & 0.0209 & 0.0281 & -0.0900 & 0.240 \\
Total taxes/GDP & 0.350 & 0.0720 & 0.108 & 0.494 \\
Cons.taxes/Total taxes & 0.326 & 0.0791 & 0.140 & 0.661 \\
Personal inc taxes/Total taxes & 0.268 & 0.103 & 0.101 & 0.586 \\
Corporate inc taxes/Total taxes & 0.0833 & 0.0441 & 0.0167 & 0.294 \\
Property taxes/Total taxes & 0.0557 & 0.0327 & 0.00834 & 0.354 \\
Social sec. cont/Total taxes & 0.267 & 0.126 & 0 & 0.496 \\
VAT/GDP & 0.0655 & 0.0179 & 0.0128 & 0.109 \\
VAT/Total taxes & 0.189 & 0.0440 & 0.0460 & 0.327 \\
Standard rate & 0.182 & 0.0505 & 0.0300 & 0.350 \\
C-efficiency & 0.553 & 0.140 & 0.225 & 1.232 \\
Consumption ratio & 2.052 & 0.662 & 1.003 & 5.815 \\
Investment & 0.230 & 0.0403 & 0.115 & 0.396 \\
Employment growth & 0.00994 & 0.0213 & -0.0806 & 0.316 \\
Total government consumption & 0.196 & 0.0371 & 0.0761 & 0.279 \\
Observations/Countries & $830 / 21$ & & & \\
\hline
\end{tabular}

Note: Statistics are based on annual data from 1970 to 2018

\footnotetext{
${ }^{16}$ Specifically, we take the following procedure to adjust the VAT standard rate data. First, we collect data on 1) the standard rate applicable on January 31 of each year $t$, and 2) the month in which any change happened (if the rate changed in a given year). Second, denoting the month of any rate change as $x$, for $x \neq 1$ we calculate the adjusted standard rate in a given year $\mathrm{t}$ as: $((x-1) / 12) *$ rate $_{t}+((12-x+1) / 12) *$ rate $_{t+1}$, where rate $_{t+1}$ is the new rate applicable on January 31 of year $t+1$. When $x=1$, namely that the new rate is applicable by January 31 of year t, we simply use rate $_{t+1}$ as the standard rate for the whole year. For example, in Japan the VAT standard rate changed on 1 April 1997 from 3 to 5 percent. With $x=4$, the adjusted rate in 1997 equals 4.5 percent $(=(3 / 12) * 3+(9 / 12) * 5)$.
} 
relatively small share of 5.6 percent, whereas social security contributions take a more substantial share of 26.7 percent. Turning to the VAT as a part of consumption taxes, the share in total taxes is 18.9 percent. This corresponds to 6.6 percent of GDP. Regarding the VAT components, the standard tax rate shows an average of 18.2 percent, while that of C-efficiency is 55.3 percent. These figures, however, mask the presence of large heterogeneity across countries and over time. For instance, C-efficiency is highest in New Zealand (97.5 percent on average over the sample period), where the VAT base is quite broad. ${ }^{17}$ The ratio of final consumption to total taxes, the last VAT component, is averaged at 205 percent. The table also contains statistics for control variables used in the regression analysis: investment rate (the share of gross fixed capital formation in GDP), employment growth, and total government consumption (the share of general government final consumption expenditure in GDP).

Figure 1 shows the evolution of the average of the ratio of the VAT to total taxes (and also to GDP), together with the VAT components, across the 21 countries over the 1993-2018 period. ${ }^{18}$ The solid (dotted) line in sub-figure (a) shows that the VAT share in total taxes (output) tended to fluctuate around 19 percent (7 percent). Both

(a) Shares of VAT in total taxes and GDP

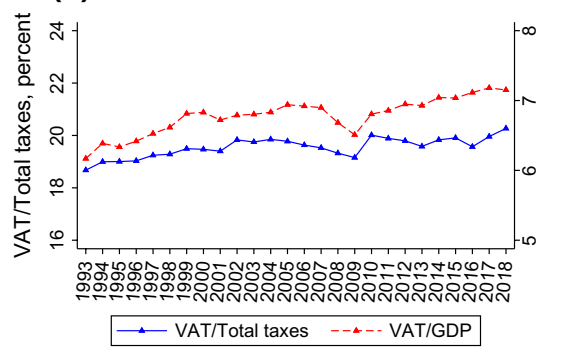

(c) C-efficiency

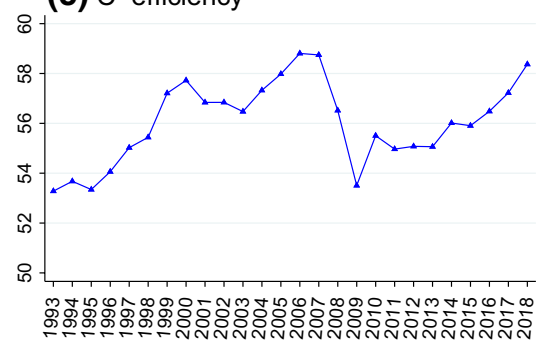

(b) Standard VAT rates

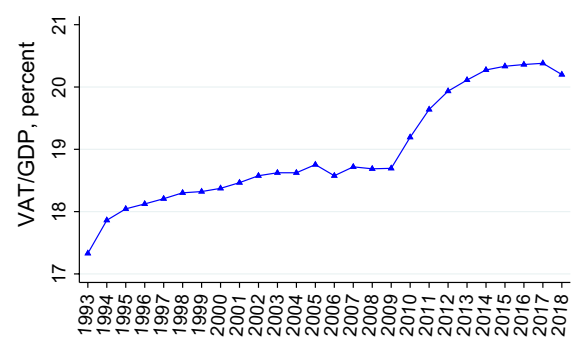

(d) Ratio of final consumption to total taxes

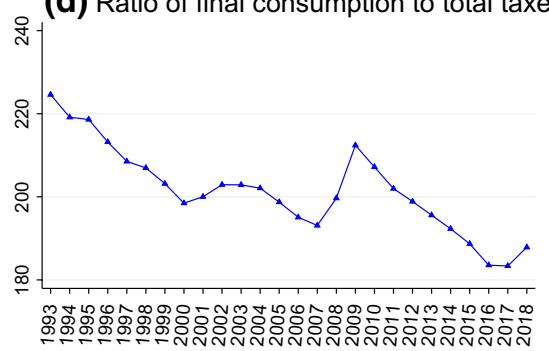

Fig. 1 Evolution of the VAT and its components in OECD countries. Notes: Average of 21 OECD countries since 1993. All figures are in percent

\footnotetext{
17 The highest value in the sample for C-efficiency belongs to Luxembourg (123.2 percent). This and other values above 100 percent reflect VAT collection which includes the effects of VAT-liable exports, such as cross-border shopping by non-residents for fuel, due to lower VAT and excise rates than in neighboring countries, and "e-VAT" collection, which is VAT levied on electronic commerce within EU taxed at origin rather than at destination (see, e.g., Ueda (2017), page 34).

18 By 1993, the data are available for all the countries included.
} 
shares increased somewhat in 2010, corresponding to a rise in the average standard rate in the same year (see sub-figure (b)). C-efficiency, in turn, exhibits more fluctuations in general, including the large fall during the crisis period (sub-figure (c)). The consumption ratio tended to fall except for the period around the crisis (subfigure (d)).

Before presenting estimation results below, we check the time series properties of the variables. Specifically, Appendix B conducts two different panel unit root tests. To summarize the results, the Maddala and Wu (1999) test, which does not require a balanced panel, rejects the null of non-stationarity for all variables considered in the baseline analysis below. Next, the Im et al. (2003) test, which also allows for an unbalanced panel and has been used extensively in the context of PMG estimated models, also shows that the null of non-stationarity is rejected for those variables (except for the log of the VAT standard rate, which cannot be tested through this method). Overall, all the key variables considered below appear to be stationary. ${ }^{19}$

\section{Results}

This section presents our main results on how the long-run growth effects of a tax reallocation between the VAT and income taxes may differ depending on whether VAT revenue is raised through C-efficiency or the standard rate. Moreover, inspired by previous works that compare the growth effects of personal and corporate income taxes (e.g., Lee and Gordon (2005), Arnold et al. (2011) and Acosta-Ormaechea et al. (2019)), we examine results on the reallocation effects of VAT components separately for these taxes. ${ }^{20}$ As noted, our focus is on results on the long-run growth effects of VAT components, which are estimated using Eq. 2 in the error correction form (cf. Eqs. 5 and 11). The error-correction speed of adjustment is reported routinely. We only present results based on the PMG method, because the Hausman test cannot reject the PMG model in all the estimations below. This means that the crosscountry homogeneity of the long-run coefficients is supported throughout.

\subsection{Does it matter how VAT revenue is raised?}

Table 2, focusing on the long-run coefficients, presents results. To start, Columns 1 and 2 show the long-run growth effects of tax reallocations toward the VAT without specifying how VAT revenue is raised. Specifically, Column 1 shows the effects of a revenue-neutral increase in the VAT, where the financing component is the sum

\footnotetext{
19 The underlying ARDL model can be used regardless of whether the variables of interest are $\mathrm{I}(0)$ or $\mathrm{I}(1)$.

20 There are mixed results in the empirical literature on the relative growth effects of these taxes. For instance, Arnold et al. (2011) find that corporate income taxes are the most harmful taxes for growth, whereas Acosta-Ormaechea et al. (2019) show that personal income taxes and social security contributions have a more detrimental growth impact than corporate income taxes.
} 
Table 2 Tax composition and growth: VAT revenue decomposed

\begin{tabular}{|c|c|c|c|c|c|c|}
\hline \multirow{5}{*}{$\begin{array}{l}\text { Estimation method } \\
\text { Financing tax } \\
\text { VAT comp } \\
\text { changed }\end{array}$} & \multicolumn{6}{|c|}{ Pooled Mean Group (PMG) } \\
\hline & \multirow{3}{*}{$\begin{array}{l}\text { Rest } \\
\text { Whole }\end{array}$} & \multicolumn{5}{|l|}{ Income taxes } \\
\hline & & Whole & C-efficiency & C-efficiency & Stand rate & Stand rate \\
\hline & & & $\&$ Cons ratio & & \& Cons ratio & \\
\hline & (1) & (2) & (3) & (4) & (5) & (6) \\
\hline \multicolumn{7}{|c|}{ Dependent variable: real GDP per capita growth } \\
\hline Total taxes/GDP & $\begin{array}{l}-0.0815 * * * \\
(-3.43)\end{array}$ & $\begin{array}{l}-0.0630 * * * \\
(-2.61)\end{array}$ & $\begin{array}{l}0.00326 \\
(0.11)\end{array}$ & $\begin{array}{l}0.201 * * * \\
(4.61)\end{array}$ & $\begin{array}{l}-0.0772 * * * \\
(-3.06)\end{array}$ & $\begin{array}{l}0.188 * * * \\
(4.36)\end{array}$ \\
\hline VAT/Total taxes & $\begin{array}{l}-0.0115 \\
(-0.47)\end{array}$ & $\begin{array}{l}0.0162 \\
(0.65)\end{array}$ & $\begin{array}{l}0.112 * * * \\
(3.20)\end{array}$ & $\begin{array}{l}0.169 * * * \\
(5.13)\end{array}$ & $\begin{array}{l}-0.0311 \\
(-1.02)\end{array}$ & $\begin{array}{l}-0.0316 \\
(-1.11)\end{array}$ \\
\hline Other taxes/Total & & $\begin{array}{l}0.0323^{*} \\
(1.89)\end{array}$ & $\begin{array}{l}0.0178 \\
(0.99)\end{array}$ & $\begin{array}{l}0.0155 \\
(0.89)\end{array}$ & $\begin{array}{l}0.0279 \\
(1.64)\end{array}$ & $\begin{array}{l}-0.00327 \\
(-0.18)\end{array}$ \\
\hline $\begin{array}{l}\text { Standard rate } \\
(\log )\end{array}$ & & & $\begin{array}{l}-0.0282 * * * \\
(-4.60)\end{array}$ & $\begin{array}{l}-0.0271 * * * \\
(-4.85)\end{array}$ & & \\
\hline C-efficiency (log) & & & & & $\begin{array}{l}0.0139 * * \\
(2.10)\end{array}$ & $\begin{array}{l}0.0358 * * * \\
(5.64)\end{array}$ \\
\hline Cons ratio $(\log )$ & & & & $\begin{array}{l}0.0584^{* * * *} \\
(5.75)\end{array}$ & & $\begin{array}{l}0.0865 * * * \\
(7.87)\end{array}$ \\
\hline Investment rate & $\begin{array}{l}0.137 * * * \\
(5.82)\end{array}$ & $\begin{array}{l}0.133 * * * \\
(5.76)\end{array}$ & $\begin{array}{l}0.0729 * * * \\
(2.74)\end{array}$ & $\begin{array}{l}0.0700 * * * \\
(2.76)\end{array}$ & $\begin{array}{l}0.113 * * * \\
(4.45)\end{array}$ & $\begin{array}{l}0.0852 * * * \\
(3.49)\end{array}$ \\
\hline Emp growth & $\begin{array}{l}0.134 * * * \\
(3.29)\end{array}$ & $\begin{array}{l}0.135 * * * \\
(3.31)\end{array}$ & $\begin{array}{l}0.112 * * * \\
(3.03)\end{array}$ & $\begin{array}{l}0.131 * * * \\
(3.54)\end{array}$ & $\begin{array}{l}0.114 * * * \\
(2.93)\end{array}$ & $\begin{array}{l}0.108^{* * *} \\
(3.16)\end{array}$ \\
\hline Govt consumption & $\begin{array}{l}-0.344 * * * \\
(-9.07)\end{array}$ & $\begin{array}{l}-0.331 * * * \\
(-8.48)\end{array}$ & $\begin{array}{l}-0.341 * * * \\
(-8.75)\end{array}$ & $\begin{array}{l}-0.359 * * * \\
(-8.77)\end{array}$ & $\begin{array}{l}-0.307 * * * \\
(-7.55)\end{array}$ & $\begin{array}{l}-0.356^{* * * *} \\
(-8.74)\end{array}$ \\
\hline EC coefficient $(\phi)$ & $\begin{array}{l}-0.852 * * * \\
(-15.92)\end{array}$ & $\begin{array}{l}-0.855 * * * \\
(-15.98)\end{array}$ & $\begin{array}{l}-0.825 * * * \\
(-16.99)\end{array}$ & $\begin{array}{l}-0.825 * * * \\
(-16.92)\end{array}$ & $\begin{array}{l}-0.835 * * * \\
(-16.29)\end{array}$ & $\begin{array}{l}-0.821 * * * \\
(-16.41)\end{array}$ \\
\hline Countries & 21 & 21 & 21 & 21 & 21 & 21 \\
\hline Observations & 830 & 830 & 830 & 830 & 830 & 830 \\
\hline Hausman, p-value & 0.735 & 0.532 & 0.504 & 0.283 & 0.863 & 0.786 \\
\hline
\end{tabular}

Notes: PMG estimations, highlighting long-run coefficients. The model in Columns (1) and (2) ((3) to (6)) is a variant of Eq. 5 (Eq. 11) with homogeneity of the long-run parameters. Total taxes are the sum of consumption taxes, personal income taxes, corporate income taxes, property taxes, and social security contributions (which includes taxes on payroll and workforce). VAT is a part of consumption taxes. In Column (1), financing taxes of "Rest" mean the sum of all taxes apart from the VAT. In Columns (2) to (6), financing taxes are (total) income taxes, the sum of personal and corporate income taxes. In those columns, Other taxes are "Total-VAT-Financing taxes (Income taxes)". Constants and short-run coefficients are not shown for brevity. t-statistics are in parentheses. $* * * p<0.01$, ** $p<0.05$, * $p<0.1$ 
of all taxes apart from the VAT, denoted as "Rest". The long-run coefficient on the VAT share in total taxes is insignificant, indicating that the VAT is not growth promoting relative to all other remaining taxes combined. Next, Column 2 specifies the tax component used to finance a rise in the VAT as income taxes (as the sum of personal and corporate income taxes). Again, the coefficient on the VAT share is insignificant, suggesting that the VAT, as a whole, is not significantly growth promoting relative to income taxes. ${ }^{21}$

Turning to Column 3, we control for the log of the standard rate, one of the VAT components, while omitting the other components (i.e., C-efficiency and the consumption ratio). In this case, the coefficient on the VAT share in total tax revenue reflects the effect of a revenue-neutral increase in VAT, financed by a fall in income taxes, when the increase in the VAT is either through a rise in C-efficiency or the consumption ratio. The coefficient on the VAT revenue share is now positive and significant at 1 percent level. The coefficient of 0.112 indicates that a one percentage point increase in the VAT revenue share through these VAT components, offset by a fall in the share of income taxes of the same size, is associated with a 0.112 percentage points increase in annual growth in the long run. In Column 4, we control for not only the standard rate, but also the consumption ratio, such that a VAT revenue increase happens only through a rise in C-efficiency. In this case, the coefficient on the VAT revenue share is still positive and significant, with an even larger coefficient of 0.169. Instead, Columns 5 and 6 control for C-efficiency (together with the consumption ratio in the latter column), disallowing this VAT component to change in the reallocation exercise. Notably, coefficients on the VAT revenue share are insignificant, suggesting that a VAT revenue increase through a rise in the standard rate is not associated with higher long-run growth.

Moreover, the fact that the coefficient on the $\log$ of C-efficiency is positive in Column 6 indicates that for a given VAT revenue, a rise in C-efficiency, offset by a fall in the standard rate (omitted component), is growth promoting. ${ }^{22}$ Consistently, in Column 4, where the omitted component is C-efficiency, the coefficient on the standard rate is negative and significant. This is how our exercise sheds light on the growth effects of compositional changes within the VAT revenue share, particularly between the standard rate and C-efficiency. ${ }^{23}$

\footnotetext{
${ }^{21}$ The results may seem inconsistent with ones in Arnold et al. (2011). They show that a revenue-neutral increase in consumption taxes, financed by a fall in income taxes, promotes long-run growth. However, it is important to recognize that we focus on the VAT, which is a component of the broader category of consumption taxes (see Table 1). Indeed, when we estimate the growth effect of an increase in consumption taxes (as a whole) offset by a fall in income taxes, the effect is positive and statistically significant. The positive effect holds regardless of whether financing taxes are personal income taxes or corporate income taxes, although the effect is larger when the offsetting factor is the latter. This suggests that corporate income taxes are more distortionary than personal income taxes in the context of our dataset. All the results on the growth effects of consumption taxes are available from the authors upon request.

22 The coefficient of 0.0358 means that a one percent increase in C-efficiency, offset by a fall in the standard rate, promotes growth by 0.0358 percentage points.

23 In fact, if the aim is just to compare the growth effects of the standard VAT rate and C-efficiency, it is not necessary to separate out income taxes in our model, i.e., not necessary to control for "other taxes/Total" in Columns 3 to 6 of Table 2, where other taxes are "total taxes excluding VAT and income
} 
Commenting on the remaining variables, in Columns 1 and 2, the negative and significant coefficient on the share of total taxes in GDP suggests that an increase in total taxes is growth reducing in the long run. Notice, however, that coefficients on the share of total taxes in output are rather positive and significant in Columns 4 and 6 , where the consumption ratio is controlled for. This happens most likely because the total tax share and the consumption ratio are highly correlated, creating a multicollinearity problem. ${ }^{24}$ Relatedly, this leads to the inaccurate estimate of the consumption ratio in those columns. ${ }^{25}$ The long-run coefficients on investment rate and employment growth are both significantly positive, while the coefficient on government consumption is negative. ${ }^{26}$ The error-correction speed of adjustment parameter $(\phi)$ is negative throughout and lower than one in absolute value, suggesting the convergence to the long-run equilibrium. The Hausman test suggests strongly that the assumption of long-run homogeneity is not rejected in all the columns (see high p-values on the tests), supporting the use of the PMG method rather than the MG method.

Next, Table 3 examines the growth effects of a rise in the VAT offset by a fall in personal and corporate income taxes separately. Columns 1 to 3 (4 to 6) estimate the models of Columns 2, 4, and 6 of Table 2 using personal (corporate) income taxes as a financing tax. Column 1 shows that a rise in VAT revenue, as a whole, does not have a significant long-run growth impact when offset by a fall in personal income taxes. However, in Column 2, where an increase in VAT revenue is only through C-efficiency, the long-run growth effect is positive and significant, whereas in Column 3, where the increase is through a rise in the standard rate, the growth effect remains insignificant. Turning to corporate income taxes as a financing tax, Column 4 shows that even when the way VAT revenue is raised is not specified, the coefficient on the VAT revenue share is significantly positive unlike the case with personal income taxes (Column 1). This suggests that corporate income taxes could be more distortionary than personal income taxes. Nonetheless, when it comes to

\footnotetext{
Footnote 23 (continued)

taxes". We obtain practically the same coefficients on the VAT components when we omit this control variable in those columns. Results are available from the authors upon request.

${ }^{24}$ The correlation coefficient is -0.90 .

${ }^{25}$ To clarify, estimating the coefficient on the consumption ratio is not our particular interest, essentially because this VAT component is not under the control of policymakers unlike the standard rate. (Although C-efficiency is not under policymakers' direct control either, policies on the VAT base and rate structure, as discussed below, are still considered to affect this component.) Still, one tentative way of considering the growth effect of the consumption ratio, if measured accurately, is to regard the ratio of consumption to total taxes as a proxy of informal (underground) economy, and then to link informal economy and growth. For example, if informal economy is measured by "revenue not reported to, and not discovered by, the tax authorities produced in underground activities (Tanzi 1999, page F344)", since it indicates that the government receives less revenue than it should, a rise in this ratio may correspond to a lager informal economy. However, as Tanzi (1999) clarifies, this is not the only possible measure of informal economy, and in general, the definition of an informal economy is quite controversial itself (see, e.g., Schneider (2005)). Thus, the growth interpretation based on the economy's degree of informality (cf. Elgin and Birinci (2016)), even if attempted, is bound to be highly debatable.

${ }^{26}$ The negative growth effect of a rise in government consumption is often observed in the growth literature (e.g., Barro and Sala-i Martin (2004)).
} 
Table 3 Income taxes separated into personal and corporate income taxes

\begin{tabular}{|c|c|c|c|c|c|c|}
\hline \multirow{3}{*}{$\begin{array}{l}\text { Estimation method } \\
\text { Financing tax } \\
\text { VAT comp changed }\end{array}$} & \multicolumn{6}{|c|}{ Pooled Mean Group (PMG) } \\
\hline & \multicolumn{3}{|c|}{ Personal income taxes } & \multicolumn{3}{|c|}{ Corporate income taxes } \\
\hline & Whole & C-efficiency & Stand rate & Whole & C-efficiency & Stand rate \\
\hline & (1) & (2) & (3) & (4) & $(5)$ & (6) \\
\hline \multicolumn{7}{|c|}{ Dependent variable: real GDP per capita growth } \\
\hline Total taxes/GDP & $\begin{array}{l}-0.0744 * * * \\
(-3.06)\end{array}$ & $\begin{array}{l}0.173 * * * \\
(3.89)\end{array}$ & $\begin{array}{l}0.168 * * * \\
(3.84)\end{array}$ & $\begin{array}{l}-0.0572 * * \\
(-2.39)\end{array}$ & $\begin{array}{l}0.183 * * * \\
(4.14)\end{array}$ & $\begin{array}{l}0.192 * * * \\
(4.33)\end{array}$ \\
\hline VAT/Total taxes & $\begin{array}{l}-0.00182 \\
(-0.07)\end{array}$ & $\begin{array}{l}0.142 * * * \\
(4.26)\end{array}$ & $\begin{array}{l}-0.0398 \\
(-1.43)\end{array}$ & $\begin{array}{l}0.0590 * \\
(1.72)\end{array}$ & $\begin{array}{l}0.162 * * * \\
(4.31)\end{array}$ & $\begin{array}{l}-0.0392 \\
(-1.10)\end{array}$ \\
\hline Other taxes/Total & $\begin{array}{l}0.0221 \\
(1.20)\end{array}$ & $\begin{array}{l}0.0222 \\
(1.17)\end{array}$ & $\begin{array}{l}0.0205 \\
(1.09)\end{array}$ & $\begin{array}{l}0.0498 * * \\
(2.14)\end{array}$ & $\begin{array}{l}0.0228 \\
(1.02)\end{array}$ & $\begin{array}{l}-0.0104 \\
(-0.44)\end{array}$ \\
\hline Standard rate (log) & & $\begin{array}{l}-0.0252^{* * *} \\
(-4.34)\end{array}$ & & & $\begin{array}{l}-0.0204 * * * \\
(-3.73)\end{array}$ & \\
\hline C-efficiency (log) & & & $\begin{array}{l}0.0362^{* * * *} \\
(5.76)\end{array}$ & & & $\begin{array}{l}0.0333 * * * \\
(5.22)\end{array}$ \\
\hline Cons ratio $(\log )$ & & $\begin{array}{l}0.0534 * * * \\
(5.31)\end{array}$ & $\begin{array}{l}0.0827 * * * \\
(7.63)\end{array}$ & & $\begin{array}{l}0.0558 * * * \\
(5.47)\end{array}$ & $\begin{array}{l}0.0838 * * * \\
(7.30)\end{array}$ \\
\hline Investment rate & $\begin{array}{l}0.136 * * * \\
(5.78)\end{array}$ & $\begin{array}{l}0.0759 * * * \\
(2.94)\end{array}$ & $\begin{array}{l}0.0834 * * * \\
(3.44)\end{array}$ & $\begin{array}{l}0.131 * * * \\
(5.60)\end{array}$ & $\begin{array}{l}0.0774 * * * \\
(3.04)\end{array}$ & $\begin{array}{l}0.0911 * * * \\
(3.75)\end{array}$ \\
\hline Emp growth & $\begin{array}{l}0.117 * * * \\
(2.88)\end{array}$ & $\begin{array}{l}0.113 * * * \\
(3.10)\end{array}$ & $\begin{array}{l}0.102 * * * \\
(3.00)\end{array}$ & $\begin{array}{l}0.167 * * * \\
(3.87)\end{array}$ & $\begin{array}{l}0.157 * * * \\
(4.03)\end{array}$ & $\begin{array}{l}0.114 * * * \\
(3.26)\end{array}$ \\
\hline Govt consumption & $\begin{array}{l}-0.341 * * * \\
(-8.88)\end{array}$ & $\begin{array}{l}-0.363 * * * \\
(-8.97)\end{array}$ & $\begin{array}{l}-0.351 * * * \\
(-8.70)\end{array}$ & $\begin{array}{l}-0.331 * * * \\
(-8.75)\end{array}$ & $\begin{array}{l}-0.363^{* * *} \\
(-9.05)\end{array}$ & $\begin{array}{l}-0.362 * * * \\
(-9.12)\end{array}$ \\
\hline EC coefficient $(\phi)$ & $\begin{array}{l}-0.852 * * * \\
(-15.29)\end{array}$ & $\begin{array}{l}-0.831 * * * \\
(-16.72)\end{array}$ & $\begin{array}{l}-0.826^{* * *} \\
(-16.35)\end{array}$ & $\begin{array}{l}-0.842 \text { *** } \\
(-16.73)\end{array}$ & $\begin{array}{l}-0.823 * * * \\
(-17.94)\end{array}$ & $\begin{array}{l}-0.818^{* * *} \\
(-17.12)\end{array}$ \\
\hline Countries & 21 & 21 & 21 & 21 & 21 & 21 \\
\hline Observations & 830 & 830 & 830 & 830 & 830 & 830 \\
\hline Hausman, p-value & 0.713 & 0.225 & 0.484 & 0.533 & 0.793 & 0.813 \\
\hline
\end{tabular}

Notes: PMG estimations, highlighting long-run coefficients. Other taxes are "Total-VAT-Financing taxes (Personal income taxes for Columns 1 to 3; Corporate income taxes for Columns 4 to 6)". For further relevant information, see notes to Table 2. t-statistics are in parentheses. $* * * p<0.01, * * p<0.05$, * $p<0.1$

the relevance of VAT components to growth, the same message emerges. That is, only when the VAT is raised through a rise in C-efficiency, the reallocation effect is positive and significant. Last, we observe again that for a given VAT revenue, an increase in C-efficiency, offset by a decrease in the standard rate, promotes growth (Columns 2, 3, 5, and 6). 


\subsection{Interpretation and discussion}

\subsubsection{Why is an increase in C-efficiency growth promoting?}

The above results indicate that in the context of OECD countries, raising the VAT through a rise in C-efficiency is more growth promoting than doing so through a rise in the standard rate. To interpret this result, it is useful to remember from Sect. 1 that in advanced economies, the deviation of C-efficiency from the value of one is mainly due to the policy gap (the VAT that is not levied due to the exemptions and reduced rates) rather than the compliance gap (the imperfect compliance of taxpayers). Then, recognizing that the literature indicates that exemptions and differentiated rates induce inefficient resource allocations, a possible interpretation of the growth-promoting effect of C-efficiency in OECD countries would be that a rise in C-efficiency, possibly reflecting the broadening of the VAT base with fewer exemptions and a more uniform rate structure with fewer reduced rates, yields efficiency gains that a rise in the standard rate might forgo.

\subsubsection{How may VAT distortions reduce long-run growth?}

We now discuss in detail how VAT distortions may reduce growth. Regarding exemptions (i.e., no tax is charged on sales, but the VAT charged on inputs is not refunded or credited), Crawford et al. (2010) indicate that the fundamental reason why exemptions are distortionary is that by breaking the chain of output tax and input credit, they create an element of production taxation. For example, input choices can be distorted, since VAT exempt entities might buy products that bear a lower VAT. ${ }^{27}$ Further, exemptions may give businesses an incentive to self-supply (to avoid production taxation entailed in input prices), hampering the contracting out of certain goods and services and possibly reducing the efficiency of their operation. Indeed, these distortions from exemptions might reduce long-run growth through different channels. Efficiency loss in resource allocation is indicative of lower total factor productivity (TFP). Moreover, Cnossen (2010) point out that the fact that exemptions are common in healthcare and education sectors increases the cost for firms wishing to conduct research through hospitals and universities, as exempted sectors cannot take credit for the VAT paid on their inputs. The increased cost, in turn, could discourage firms' research activities, eventually dampening growth through lower TFP. Besides, because firms in exempted sectors are unable to recover the VAT on their spending including that on capital goods, firms' physical investment may be discouraged, lowering capital accumulation and thus growth. Next, VAT differentiated rates, which are caused both by reduced rates and exemptions, may also have a negative macroeconomic impact. First, the presence of multiple VAT rates generates well-cited costs associated with increased administration costs (e.g., Ebrill et al. 2001). Second, potentially more fundamentally, rate differentiation

\footnotetext{
27 Since financial sectors are often exempted, the distorting effects can be cascading further into the costs of businesses using financial services.
} 
distorts consumer choices by affecting the relative prices of goods and services, although their macroeconomic influence is rather speculative.

There is an indication that these distortions from exemptions and differentiated rates might be quantitatively relevant. First, unrecoverable VAT liabilities from intermediate inputs purchased by sectors producing exempted supplies appears substantial in practice. For example, according to Netherlands Bureau for Economic Policy Analysis (2015), in 2011 in EU-27 countries unrecoverable VAT liabilities accounted for 19 percent of all VAT liabilities (defined as the total amount of the VAT households and non-households are supposed to pay, given their expenditure and the respective VAT rates). In the context of the EU, one key institutional detail about the VAT system, after the EU VAT directive of "Council Directive 2006/112/ EC on the common system of value-added tax (Council VAT Directive 2006)", is that most exemptions have been harmonized for EU countries, while they have more discretion in setting their country-level standard and reduced rates. This suggests that distortions of exemptions are relevant throughout the EU. ${ }^{28}$ Further, to gauge the extent of rate differentiation, it is useful to look at the "effective" VAT rate calculated by Netherlands Bureau for Economic Policy Analysis (2015). ${ }^{29}$ They indicate that in 2011 in EU-27, the effective rate was 9 percent on average, while the average of standard rates was 20.7 percent. This large difference reflects the widespread use of rate differentiation in the EU.

\subsubsection{Investigating mechanisms}

To shed some more light on how an increase in C-efficiency may promote longrun growth, we conduct one additional analysis. Regressions thus far assumed implicitly that C-efficiency and other components of the VAT affect growth mainly through total factor productivity (TFP), by controlling for the investment rate and employment growth, whereas Table 4, focusing on total income taxes as a financing tax component, allows the VAT to affect growth through capital accumulation or employment. To start, Columns 1 and 2 replicate Columns 4 and 6 of Table 2 for convenience (where both investment rate and employment growth are controlled for), and Columns 3 and 4 (5 and 6) omit investment rate (employment growth). The basic message of the estimations stays the same, in that only when VAT revenue increases through C-efficiency, long-run growth is promoted. However, in Column 3 , while the coefficient on the VAT revenue ratio (0.173) is still significant, its magnitude is only slightly larger the one in Column 1. Likewise, in Column 5 (where

\footnotetext{
${ }_{28}$ Cnossen (2020) discusses the issues caused by the exemption system under the Council VAT Directive for the Dutch case and proposes the move toward a modern VAT that applies a uniform rate to the broadest possible base.

29 This effective rate, obtained as VAT liabilities divided by the tax base, contains information on how much households and non-households pay on their consumption, after reduced (and zero) rates and exemptions are taken into account.
} 
Table 4 On channels through which VAT components matter

\begin{tabular}{|c|c|c|c|c|c|c|}
\hline \multirow{5}{*}{$\begin{array}{l}\text { Estimation method } \\
\text { Financing tax } \\
\text { VAT comp changed } \\
\text { Variables omitted }\end{array}$} & \multicolumn{6}{|c|}{ Pooled Mean Group (PMG) } \\
\hline & \multicolumn{6}{|l|}{ Income taxes } \\
\hline & C-efficiency & Stand rate & C-efficiency & Stand rate & C-efficiency & Stand rate \\
\hline & \multicolumn{2}{|l|}{ None } & \multicolumn{2}{|c|}{ Investment rate } & \multicolumn{2}{|c|}{ Employment growth } \\
\hline & (1) & (2) & (3) & (4) & (5) & (6) \\
\hline \multicolumn{7}{|c|}{ Dependent variable: real GDP per capita growth } \\
\hline Total taxes/GDP & $\begin{array}{l}0.201 * * * \\
(4.61)\end{array}$ & $\begin{array}{l}0.188 * * * \\
(4.36)\end{array}$ & $\begin{array}{l}0.211^{* * *} \\
(4.93)\end{array}$ & $\begin{array}{l}0.194 * * * \\
(4.55)\end{array}$ & $\begin{array}{l}0.173 * * * \\
(3.63)\end{array}$ & $\begin{array}{l}0.157 * * * \\
(3.36)\end{array}$ \\
\hline VAT/Total taxes & $\begin{array}{l}0.169^{* * * *} \\
(5.13)\end{array}$ & $\begin{array}{l}-0.0316 \\
(-1.11)\end{array}$ & $\begin{array}{l}0.173 * * * \\
(5.35)\end{array}$ & $\begin{array}{l}-0.0563 * * \\
(-1.99)\end{array}$ & $\begin{array}{l}0.160 * * * \\
(4.68)\end{array}$ & $\begin{array}{l}-0.0384 \\
(-1.31)\end{array}$ \\
\hline Other taxes/Total taxes & $\begin{array}{l}0.0155 \\
(0.89)\end{array}$ & $\begin{array}{l}-0.00327 \\
(-0.18)\end{array}$ & $\begin{array}{l}0.00951 \\
(0.54)\end{array}$ & $\begin{array}{l}-0.00727 \\
(-0.40)\end{array}$ & $\begin{array}{l}0.00757 \\
(0.42)\end{array}$ & $\begin{array}{l}-0.0134 \\
(-0.73)\end{array}$ \\
\hline Standard rate $(\log )$ & $\begin{array}{l}-0.0271 * * * \\
(-4.85)\end{array}$ & & $\begin{array}{l}-0.0299 * * * \\
(-5.78)\end{array}$ & & $\begin{array}{l}-0.0271 * * * \\
(-4.85)\end{array}$ & \\
\hline C-efficiency $(\log )$ & & $\begin{array}{l}0.0358 * * * \\
(5.64)\end{array}$ & & $\begin{array}{l}0.0387 * * * \\
(6.26)\end{array}$ & & $\begin{array}{l}0.0332 * * * \\
(5.18)\end{array}$ \\
\hline Cons ratio $(\log )$ & $\begin{array}{l}0.0584 * * * \\
(5.75)\end{array}$ & $\begin{array}{l}0.0865^{* * * *} \\
(7.87)\end{array}$ & $\begin{array}{l}0.0648 * * * \\
(6.10)\end{array}$ & $\begin{array}{l}0.0950 * * * \\
(8.34)\end{array}$ & $\begin{array}{l}0.0568 * * * \\
(5.29)\end{array}$ & $\begin{array}{l}0.0836^{* * * *} \\
(7.28)\end{array}$ \\
\hline Govt consumption & $\begin{array}{l}-0.359 * * * \\
(-8.77)\end{array}$ & $\begin{array}{l}-0.356^{* * *} \\
(-8.74)\end{array}$ & $\begin{array}{l}-0.403 * * * \\
(-9.88)\end{array}$ & $\begin{array}{l}-0.407 * * * \\
(-10.02)\end{array}$ & $\begin{array}{l}-0.376^{* * *} \\
(-8.55)\end{array}$ & $\begin{array}{l}-0.382 * * * \\
(-8.78)\end{array}$ \\
\hline Investment rate & $\begin{array}{l}0.0700 * * * \\
(2.76)\end{array}$ & $\begin{array}{l}0.0852 * * * \\
(3.49)\end{array}$ & & & $\begin{array}{l}0.0344 \\
(1.33)\end{array}$ & $\begin{array}{l}0.0490 * * \\
(1.98)\end{array}$ \\
\hline Emp growth & $\begin{array}{l}0.131 * * * \\
(3.54)\end{array}$ & $\begin{array}{l}0.108 * * * \\
(3.16)\end{array}$ & $\begin{array}{l}0.235^{* * * *} \\
(5.75)\end{array}$ & $\begin{array}{l}0.207 * * * \\
(5.27)\end{array}$ & & \\
\hline EC coefficient $(\phi)$ & $\begin{array}{l}-0.825 * * * \\
(-16.92)\end{array}$ & $\begin{array}{l}-0.821 * * * \\
(-16.41)\end{array}$ & $\begin{array}{l}-0.792 * * * \\
(-16.23)\end{array}$ & $\begin{array}{l}-0.786 * * * \\
(-15.86)\end{array}$ & $\begin{array}{l}-0.848 * * * \\
(-18.67)\end{array}$ & $\begin{array}{l}-0.852 * * * \\
(-18.34)\end{array}$ \\
\hline Countries & 21 & 21 & 21 & 21 & 21 & 21 \\
\hline Observations & 830 & 830 & 830 & 830 & 830 & 830 \\
\hline Hausman, p-value & 0.283 & 0.786 & 0.873 & 0.859 & 0.983 & 0.999 \\
\hline
\end{tabular}

Notes: PMG estimations, highlighting long-run coefficients. For further relevant information, see notes to Table 2. t-statistics are in parentheses. $* * * p<0.01, * * p<0.05, * p<0.1$ 
employment growth is left out), the magnitude of the coefficient on the VAT revenue is somewhat similar (0.160). Therefore, an indication, albeit tentative, is that an increase in C-efficiency may promote growth mainly through higher TFP. ${ }^{30}$

\subsubsection{Caveats}

To conclude our interpretation and discussion on the results on the growth effect of C-efficiency, we provide important caveats in relation to its cyclicality. Figure 2 shows that within our sample the association between C-efficiency (as a deviation from the national average over the sample period) and the output gap is positive and significant (see the OLS fitted line). ${ }^{31}$ This is a well-known cyclical feature of C-efficiency reported in the literature (see Sect. 2 for review). Fundamentally, this suggests that variations in C-efficiency reflect much more than the variations caused by VAT policy reforms of the breadth of the VAT base and rate differentiation, which are rather infrequent. The first caveat to note is thus that there is an inherent difficulty in interpreting the growth effect of C-efficiency as the effect of those policy reforms per se. ${ }^{32}$ The second related caveat is that this cyclicality might generate an

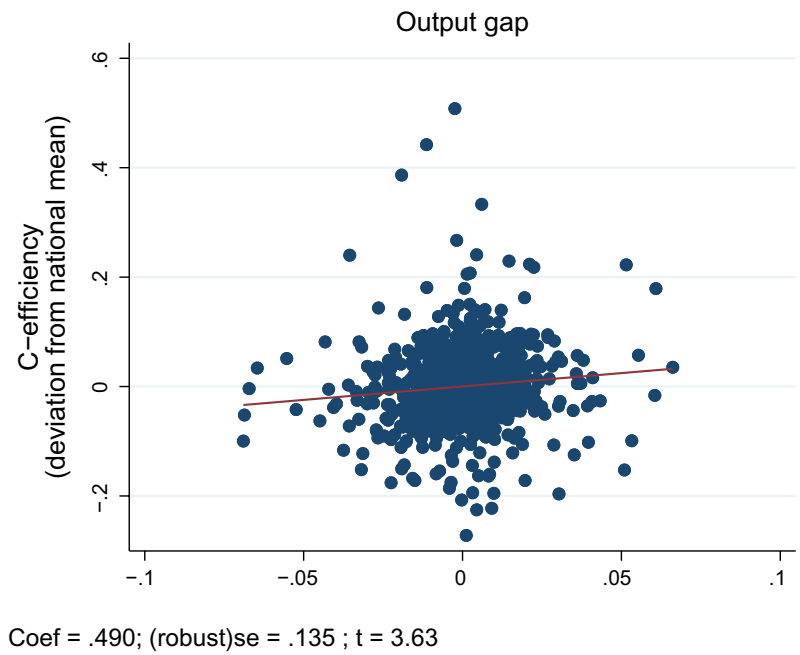

Fig. 2 Cyclicality of C-efficiency. Notes: 830 observations from 21 countries are pooled. Clustered standard errors are used to adjust for correlation of error terms within countries

\footnotetext{
${ }^{30}$ If the investment channel is critical, for instance, we would expect a more distinctive increase in the coefficient on the VAT revenue share when investment rate is not controlled for.

31 Output gap is calculated as log difference between real GDP and its trend by using the HodrickPrescott filter.

32 To shed light on the link between C-efficiency and actual reforms to the VAT design formally, we looked into the Tax Policy Reform Database (TPRD) introduced by Amaglobeli et al. (2018), which covers tax policy reforms (including the VAT reforms) in 23 advanced and emerging market economies since the 1970s. Specifically, we investigated how VAT base-changing and rate-differentiating reforms might be associated with a change in C-efficiency around the year when a reform was implemented, after
} 
endogeneity concern due to a possible reverse causality problem. Overall, while we show below that our results appear to be robust to endogeneity concerns due to business cycle fluctuations, the fact that various factors may affect $\mathrm{C}$-efficiency makes it inherently difficult to interpret the growth effect of C-efficiency.

\subsection{Robustness}

This section conducts robustness checks for the key result that a revenue-neutral increase in the VAT, financed by a fall in income taxes, promotes long-run growth only when the VAT is raised through a rise in C-efficiency.

\subsubsection{Robustness tests}

Endogeneity Here, we aim to mitigate the aforementioned endogeneity concern associated with the cyclicality of C-efficiency. This concern might be more general, as illustrated by the cyclicality of the share of income taxes (see Appendix C). In what follows, our approach to mitigate this endogeneity concern is twofold.

First, based on Bleaney et al. (2001) and Gemmell et al. (2011), we estimate a model that disallows the contemporaneous relation between tax variables and growth. Specifically, in Eq. 2, we now impose $\delta_{0 i}=0$. This yields:

$$
g_{i, t}=\mathbf{f}_{i, t-1}^{\prime} \delta_{1 i}+\lambda_{i} g_{i, t-1}+\sum_{j=1}^{n} \gamma_{0 i, j} z_{i, j, t}+\sum_{j=1}^{n} \gamma_{1 i, j} z_{i, j, t-1}+\epsilon_{i, t} .
$$

Here, for the reverse causality argument to hold, the government's expectation of the future growth rate would have to cause a change in present tax composition. Although this is possible, the problem may be less severe than the case with the contemporaneous relation, where, say, (currently) slow-growing countries change the tax composition in an attempt to grow faster. Second, we use an adjusted measure of C-efficiency, which is purged of the business cycle effects. Specifically, we first regress (the log of) C-efficiency on the output gap on a country-by-country basis using OLS, and take the residual, which would represent C-efficiency purged of the business cycle effects. Then, we use this adjusted C-efficiency variable to shed light on the relevance of VAT components to growth using the PMG method. ${ }^{33}$

\footnotetext{
Footnote 32 (continued)

controlling for a change in the output gap (as a proxy for business cycles) as well as country-specific factors. Highlighting 121 VAT reforms in 17 OECD countries between 1970 and 2014, we obtained some preliminary results that suggest, as expected, that there is a positive relationship between C-efficiency and a reform that is considered to broaden base and/or lead to a more uniform rate structure. To admit, however, the analysis is strictly preliminary, because although the TPRD gives a natural starting point for this type of investigation, a more extensive data gathering effort, especially on the quantitative and multiyear dimensions of a reform in several countries over those decades, would be required to have more reliable results. Still, those preliminary results are available from the authors upon request.

${ }^{33}$ While these exercises are an important robustness check, it is useful to point out that there is some ambiguity regarding the extent to which the cyclicality of C-efficiency impacts our estimates, since our interest is to estimate the effect of C-efficiency on growth (within the context of the revenue-neutral tax
} 
Considering the effect of the global financial crisis Next, it is often argued that, after the global financial crisis of 2007-09, there may have been a systematic downward shift in the growth pattern in advanced economies. In line with this argument, in our sample of 21 OECD countries, the average GDP per capita growth over 1993-2007 is 2.58 percent, whereas it is 1.51 percent over 2010-18. One theoretical explanation for the apparent change is the secular stagnation hypothesis of Summers (2014). Acknowledging this possibility, we consider a model which contains an after-crisis dummy that takes the value of one for years after 2008 (inclusive).

Controlling for human capital variable In the models considered above, we did not explicitly account for the role of human capital as a factor of production. Acknowledging this, although it is in general quite challenging to measure the level of human capital particularly in the context of an annual dataset over a long time period, we tentatively control for it here, using years of schooling (population aged 15-64) available from Barro and Lee (2013). Note, however, that since the data are available only every 5 years, interpolated values are used. ${ }^{34}$

Expanding the lag structure of the ARDL model The analysis above uses an ARDL structure, where both dependent and independent variables are included with a lag of order 1 . We now consider expanding the lag structure for robustness. As noted, however, with the use of PMG (and MG) estimators, a degree of freedom problem is soon reached unless the available time series is very long. This is particularly the case with our interest in decomposing VAT revenue. Given this, we chose to use a richer lag structure only for growth (the dependent variable) and tax variables (the variables of interest), keeping one lag of each remaining control variable as before. ${ }^{35}$ Specifically, using two lags for growth and tax variables, Eq. 2 becomes:

$$
g_{i, t}=\sum_{k=0}^{2} \mathbf{f}_{i, t-k}^{\prime} \delta_{k i}+\sum_{m=1}^{2} \lambda_{m i} g_{i, t-m}+\sum_{p=0}^{1} \sum_{j=1}^{n} \gamma_{p i, j} z_{i, j, t-p}+\epsilon_{i, t}
$$

To accommodate this change, we ensure that at least 30 (instead of 25 as above) annual successive observations are available for each country. The caveat is that since several countries adopted the VAT in the late 80s to early 90s (e.g., Japan), using a longer series reduces the number of countries.

\subsubsection{Test results}

Tables 5 and 6 present test results. For brevity, we only consider total income taxes as a financing tax component, and routinely control for both investment rate and employment growth. We use the PMG method as before, focusing on long-run

\footnotetext{
Footnote 33 (continued)

allocations). Indeed, the correlation between growth and the output gap is positive, but not that high (the correlation coefficient is 0.42 in our dataset).

34 Also, since the data stop at 2010, we use projected data (provided in their dataset) for 2015 and 2020.

35 In the context of PMG/MG estimations, Loayza and Rancière (2006) adopt a similar approach to avoid running into problems of lack of degrees of freedom.
} 
Table 5 Robustness tests 1: Endogeneity

\begin{tabular}{|c|c|c|c|c|c|c|}
\hline \multirow{6}{*}{$\begin{array}{l}\text { Robustness checks } \\
\text { Estimation method } \\
\text { Financing tax } \\
\text { VAT comp changed }\end{array}$} & \multirow{2}{*}{\multicolumn{2}{|c|}{$\frac{\text { No contemp relation }}{\text { Pooled Mean Group }}$}} & \multicolumn{4}{|c|}{ Using adjusted C-efficiency } \\
\hline & & & & & & \\
\hline & \multicolumn{6}{|l|}{ Income taxes } \\
\hline & C-efficiency & Stand rate & Stand rate & Stand rate & Stand rate & Stand rate \\
\hline & & & \& Cons ratio & $\&$ Cons ratio & & \\
\hline & (1) & (2) & (3) & (4) & (5) & (6) \\
\hline \multicolumn{7}{|c|}{ Dependent variable: real GDP per capita growth } \\
\hline Total taxes/GDP & $\begin{array}{l}0.0908 * * \\
(2.18)\end{array}$ & $\begin{array}{l}0.102 * * \\
(2.47)\end{array}$ & $\begin{array}{l}-0.0772 * * * \\
(-3.06)\end{array}$ & $\begin{array}{l}-0.0688 * * * \\
(-2.80)\end{array}$ & $\begin{array}{l}0.188 * * * \\
(4.36)\end{array}$ & $\begin{array}{l}0.201 * * * \\
(4.86)\end{array}$ \\
\hline VAT/Total taxes & $\begin{array}{l}0.0766 * * \\
(2.46)\end{array}$ & $\begin{array}{l}-0.0225 \\
(-0.82)\end{array}$ & $\begin{array}{l}-0.0311 \\
(-1.02)\end{array}$ & $\begin{array}{l}-0.0534^{*} \\
(-1.83)\end{array}$ & $\begin{array}{l}-0.0316 \\
(-1.11)\end{array}$ & $\begin{array}{l}-0.0385 \\
(-1.43)\end{array}$ \\
\hline Other/Total taxes & $\begin{array}{l}0.0348 * * \\
(2.13)\end{array}$ & $\begin{array}{l}0.0221 \\
(1.34)\end{array}$ & $\begin{array}{l}0.0279 \\
(1.64)\end{array}$ & $\begin{array}{l}0.0123 \\
(0.73)\end{array}$ & $\begin{array}{l}-0.00327 \\
(-0.18)\end{array}$ & $\begin{array}{l}-0.0215 \\
(-1.27)\end{array}$ \\
\hline Standard rate $(\log )$ & $\begin{array}{l}-0.0119 * * \\
(-2.13)\end{array}$ & & & & & \\
\hline C-efficiency $(\log )$ & & $\begin{array}{l}0.0229 * * * \\
(3.72)\end{array}$ & $\begin{array}{l}0.0139 * * \\
(2.10)\end{array}$ & & $\begin{array}{l}0.0358 * * * \\
(5.64)\end{array}$ & \\
\hline $\begin{array}{l}\text { Adjusted C-efficiency } \\
(\log )\end{array}$ & & & & $\begin{array}{l}0.0231 * * * \\
(3.49)\end{array}$ & & $\begin{array}{l}0.0400 * * * \\
(6.49)\end{array}$ \\
\hline Cons ratio $(\log )$ & $\begin{array}{l}0.0396 * * * \\
(3.92)\end{array}$ & $\begin{array}{l}0.0590 * * * \\
(5.42)\end{array}$ & & & $\begin{array}{l}0.0865 * * * \\
(7.87)\end{array}$ & $\begin{array}{l}0.0906^{* * * *} \\
(8.44)\end{array}$ \\
\hline Govt consumption & $\begin{array}{l}-0.382 * * * \\
(-9.87)\end{array}$ & $\begin{array}{l}-0.375 * * * \\
(-9.78)\end{array}$ & $\begin{array}{l}-0.307 * * * \\
(-7.55)\end{array}$ & $\begin{array}{l}-0.302 * * * \\
(-7.76)\end{array}$ & $\begin{array}{l}-0.356^{* * * *} \\
(-8.74)\end{array}$ & $\begin{array}{l}-0.347 * * * \\
(-8.90)\end{array}$ \\
\hline Investment rate & $\begin{array}{l}0.0910 * * * \\
(3.58)\end{array}$ & $\begin{array}{l}0.0863 * * * \\
(3.58)\end{array}$ & $\begin{array}{l}0.113 * * * \\
(4.45)\end{array}$ & $\begin{array}{l}0.100 * * * \\
(4.14)\end{array}$ & $\begin{array}{l}0.0852 * * * \\
(3.49)\end{array}$ & $\begin{array}{l}0.0722 * * * \\
(3.29)\end{array}$ \\
\hline Emp growth & $\begin{array}{l}0.179 * * * \\
(4.31)\end{array}$ & $\begin{array}{l}0.179 * * * \\
(4.44)\end{array}$ & $\begin{array}{l}0.114 * * * \\
(2.93)\end{array}$ & $\begin{array}{l}0.0954 * * * \\
(2.72)\end{array}$ & $\begin{array}{l}0.108 * * * \\
(3.16)\end{array}$ & $\begin{array}{l}0.103 * * * \\
(3.22)\end{array}$ \\
\hline EC coefficient $(\phi)$ & $\begin{array}{l}-0.867 * * * \\
(-17.29)\end{array}$ & $\begin{array}{l}-0.868 * * * \\
(-16.98)\end{array}$ & $\begin{array}{l}-0.835 * * * \\
(-16.29)\end{array}$ & $\begin{array}{l}-0.836 * * * \\
(-16.26)\end{array}$ & $\begin{array}{l}-0.821 * * * \\
(-16.41)\end{array}$ & $\begin{array}{l}-0.825 * * * \\
(-17.74)\end{array}$ \\
\hline Countries & 21 & 21 & 21 & 21 & 21 & 21 \\
\hline Observations & 830 & 830 & 830 & 830 & 830 & 830 \\
\hline Hausman, $p$-value & 0.611 & 0.841 & 0.863 & 0.691 & 0.786 & 0.804 \\
\hline
\end{tabular}

Notes: PMG estimations, highlighting long-run coefficients. Columns 1 and 2 are based on Eq. 12, which disallows the contemporaneous relation between tax variables and growth. Columns 3 and 5 replicate Columns 5 and 6 of Table 2 to compare with Columns 4 and 6 of this table. The latter columns use adjusted C-efficiency, which is the residual obtained by regressing (the log of) C-efficiency on the output gap country by country using OLS. For further relevant information, see notes to Table 2. t-statistics are in parentheses. $* * * p<0.01, * * p<0.05, * p<0.1$

coefficients. To confirm, the Hausman test supports the use of the PMG estimator throughout. 
Table 6 Robustness tests 2: Other checks

\begin{tabular}{|c|c|c|c|c|c|c|}
\hline \multirow{4}{*}{$\begin{array}{l}\text { Robustness checks } \\
\text { Estimation method } \\
\text { Financing tax } \\
\text { VAT comp changed }\end{array}$} & \multirow{2}{*}{\multicolumn{2}{|c|}{$\frac{\text { Considering crisis }}{\text { Pooled Mean Group }}$}} & \multicolumn{2}{|c|}{ Human capital } & \multicolumn{2}{|l|}{2 lags } \\
\hline & & & & & & \\
\hline & \multicolumn{6}{|l|}{ Income taxes } \\
\hline & C-efficiency & Stand rate & C-efficiency & Stand rate & C-efficiency & Stand rate \\
\hline & (1) & (2) & (3) & (4) & (5) & (6) \\
\hline \multicolumn{7}{|c|}{ Dependent variable: real GDP per capita growth } \\
\hline Total tax/GDP & $\begin{array}{l}-0.0285 \\
(-0.60)\end{array}$ & $\begin{array}{l}-0.0370 \\
(-0.77)\end{array}$ & $\begin{array}{l}0.206 * * * \\
(4.72)\end{array}$ & $\begin{array}{l}0.201 * * * \\
(4.66)\end{array}$ & $\begin{array}{l}0.138 * * \\
(2.12)\end{array}$ & $\begin{array}{l}0.158 * * \\
(2.41)\end{array}$ \\
\hline VAT/Total taxes & $\begin{array}{l}0.152 * * * \\
(4.70)\end{array}$ & $\begin{array}{l}-0.0234 \\
(-0.81)\end{array}$ & $\begin{array}{l}0.173 * * * \\
(5.20)\end{array}$ & $\begin{array}{l}-0.0188 \\
(-0.67)\end{array}$ & $\begin{array}{l}0.141 * * * \\
(3.30)\end{array}$ & $\begin{array}{l}-0.0571 \\
(-1.47)\end{array}$ \\
\hline Other/Total taxes & $\begin{array}{l}0.0173 \\
(1.08)\end{array}$ & $\begin{array}{l}0.00900 \\
(0.55)\end{array}$ & $\begin{array}{l}0.0108 \\
(0.61)\end{array}$ & $\begin{array}{l}-0.00741 \\
(-0.41)\end{array}$ & $\begin{array}{l}0.00389 \\
(0.17)\end{array}$ & $\begin{array}{l}-0.000200 \\
(-0.01)\end{array}$ \\
\hline Standard rate $(\log )$ & $\begin{array}{l}-0.0246^{* * * *} \\
(-4.81)\end{array}$ & & $\begin{array}{l}-0.0226 * * * \\
(-4.18)\end{array}$ & & $\begin{array}{l}-0.0426 * * * \\
(-5.85)\end{array}$ & \\
\hline C-efficiency (log) & & $\begin{array}{l}0.0250 * * * \\
(3.92)\end{array}$ & & $\begin{array}{l}0.0364 * * * \\
(5.58)\end{array}$ & & $\begin{array}{l}0.0395 * * * \\
(5.47)\end{array}$ \\
\hline Cons ratio (log) & $\begin{array}{l}-0.00528 \\
(-0.44)\end{array}$ & $\begin{array}{l}0.0173 \\
(1.40)\end{array}$ & $\begin{array}{l}0.0621 * * * \\
(6.16)\end{array}$ & $\begin{array}{l}0.0905^{* * * *} \\
(7.99)\end{array}$ & $\begin{array}{l}0.0419^{* * * *} \\
(3.15)\end{array}$ & $\begin{array}{l}0.0901 * * * \\
(6.26)\end{array}$ \\
\hline Investment rate & $\begin{array}{l}0.0264 \\
(1.14)\end{array}$ & $\begin{array}{l}0.0403 * \\
(1.74)\end{array}$ & $\begin{array}{l}0.0721 * * * \\
(2.88)\end{array}$ & $\begin{array}{l}0.0864 * * * \\
(3.60)\end{array}$ & $\begin{array}{l}0.0715^{* *} \\
(2.13)\end{array}$ & $\begin{array}{l}0.0890 * * * \\
(2.68)\end{array}$ \\
\hline Emp growth & $\begin{array}{l}0.238 * * * \\
(6.03)\end{array}$ & $\begin{array}{l}0.234 * * * \\
(5.95)\end{array}$ & $\begin{array}{l}0.153 * * * \\
(3.95)\end{array}$ & $\begin{array}{l}0.122 * * * \\
(3.50)\end{array}$ & $\begin{array}{l}0.103 * * * \\
(2.79)\end{array}$ & $\begin{array}{l}0.112^{* * *} \\
(2.91)\end{array}$ \\
\hline Govt consumption & $\begin{array}{l}-0.146^{* * * *} \\
(-3.10)\end{array}$ & $\begin{array}{l}-0.164 * * * \\
(-3.45)\end{array}$ & $\begin{array}{l}-0.326^{* * * *} \\
(-7.40)\end{array}$ & $\begin{array}{l}-0.335 * * * \\
(-7.64)\end{array}$ & $\begin{array}{l}-0.488 * * * \\
(-8.81)\end{array}$ & $\begin{array}{l}-0.460 * * * \\
(-8.33)\end{array}$ \\
\hline Human cap growth & & & $\begin{array}{l}0.0806 \\
(1.03)\end{array}$ & $\begin{array}{l}-0.00183 \\
(-0.02)\end{array}$ & & \\
\hline EC coefficient $(\phi)$ & $\begin{array}{l}-0.908 * * * \\
(-17.42)\end{array}$ & $\begin{array}{l}-0.909 * * * \\
(-17.68)\end{array}$ & $\begin{array}{l}-0.835 * * * \\
(-16.47)\end{array}$ & $\begin{array}{l}-0.826 * * * \\
(-15.90)\end{array}$ & $\begin{array}{l}-0.652 * * * \\
(-8.78)\end{array}$ & $\begin{array}{l}-0.651 * * * \\
(-9.16)\end{array}$ \\
\hline After-crisis & $\begin{array}{l}-0.0117 * * * \\
(-5.57)\end{array}$ & $\begin{array}{l}-0.0112 * * * \\
(-5.32)\end{array}$ & & & & \\
\hline Countries & 21 & 21 & 21 & 21 & 16 & 16 \\
\hline Observations & 830 & 830 & 828 & 828 & 674 & 674 \\
\hline Hausman, p-value & 0.730 & 0.663 & 0.590 & 0.217 & 0.848 & 0.961 \\
\hline
\end{tabular}

Notes: PMG estimations, highlighting long-run coefficients. After-crisis dummy takes the value of one for years after 2008 (inclusive). Human capital growth is based on years of schooling (population aged 15-64) available from Barro and Lee (2013). For Columns 5 and 6, the underlying model with expanded lag structure is Eq. 13. For further relevant information, see notes to Table 2. t-statistics are in parentheses. *** $p<0.01, * * p<0.05, * p<0.1$

Columns 1 and 2 of Table 5 examine the model without the contemporaneous relation between tax variables and growth (Eq. 12), which is less susceptible to the reverse causality problem. Column 1 (2) omits C-efficiency (the standard rate) among the VAT components. The results indicate that 1) an increase in VAT 
revenue, financed by income taxes, fosters growth, only when it is through a rise in C-efficiency, and 2) for a given VAT revenue, an increase in C-efficiency, offset by a fall in the standard rate, also promotes growth. Next, we turn to the exercise using C-efficiency purged of the business cycle effects, called adjusted C-efficiency. First, Columns 3 and 5 replicate Columns 5 and 6 of Table 2, where (actual) C-efficiency, and $\mathrm{C}$-efficiency and the consumption ratio are included as VAT components, respectively. Columns 4 and 6 , in comparison with those columns, use adjusted C-efficiency instead. Notice that in Columns 4 and 6 , the coefficients on adjusted $\mathrm{C}$-efficiency stay positive and significant, suggesting that for a given VAT revenue, an increase in adjusted C-efficiency is still promoting growth, regardless of whether the consumption ratio is controlled for. Admittedly, the adjustment made to C-efficiency complicates the interpretation of the coefficients, including the ones on the ratio of the VAT to total taxes. ${ }^{36}$ Nonetheless, we regard these results as additional supporting evidence that our findings are robust to endogeneity concerns due to the cyclicality of C-efficiency.

Turning to the remaining robustness checks, Columns 1 and 2 of Table 6 confirm that the results persist even when the after-crisis dummy is controlled for. As expected, the dummy coefficient is negative and significant, suggesting the downward shift of the growth rate after the crisis. Columns 3 and 4 indicate that adding the (interpolated) human capital variable also does not change the results. The coefficient on the variable is not significant, however, perhaps reflecting the difficulty of measuring human capital in the annual framework. Last, Columns 5 and 6 show that the results are also robust to using the richer (longer) lag structure for growth and tax variables, despite the fact that the sample now reduces to 16 countries.

\section{Conclusion}

This paper investigated how the long-run growth effect of the VAT may differ depending on whether it is raised through C-efficiency or the standard rate. We showed that an increase in VAT revenue, financed by a fall in income taxes, promotes growth only when this happens through a rise in C-efficiency, but not when this happens through a rise in the standard rate. The result held even when we considered personal and corporate income taxes separately as a financing tax component. We also showed that, for a given VAT revenue, an increase in C-efficiency, offset by a decrease in the standard rate, fosters growth. This suggests that the former is significantly more growth friendly than the latter. Further, we provided some indication that a rise in C-efficiency promotes growth mainly through higher total factor productivity.

\footnotetext{
36 The difficulty stems from the fact that the estimated equation (Eq. 11) is the one derived using the approximation method that involves actual (not adjusted) C-efficiency (Eq. 9).
} 
The previous literature suggests that the deviation of C-efficiency from unity in advanced economies is largely due to the VAT that is not levied because of exemptions and reduced rates (rather than due to compliance issues). Meanwhile, it is well known that those VAT design features, that have been common in many advanced economies including EU member countries, distort resource allocations significantly. Taken together, one possible interpretation of our results is that in the long run, an increase in C-efficiency, possibly reflecting the broadening of the VAT base through fewer exemptions and a more uniform rate structure with fewer reduced rates, has a growth-promoting effect relative to a rise in the VAT standard rate that forgoes the efficiency gains. However, it is important to recognize that the estimated effect of C-efficiency cannot be seen as the effect of policy reforms of the VAT base and differentiated rates per se, because variations in C-efficiency are likely to reflect much more than the variations caused by those reforms.

Further, while this paper contributes to the literature on taxation and growth by highlighting the relevance of tax design, which has been largely ignored previously, it is important to acknowledge that there is a limitation to the VAT decomposition method used here. Specifically, as Keen (2013) emphasizes, it does not capture the behavioral responses of taxpayers to policy changes. For example, our exercise is silent on possible changes in taxpayers' compliance behavior induced by a change in the VAT standard rate. This is a methodological limitation, although the problem might not be severe in our context of OECD countries where, unlike developing countries, a compliance issue does not appear to be a significant determinant of C-efficiency.

To conclude, although this paper highlighted the relevance of VAT design in the context of long-run growth, growth is clearly not the only aspect a government is concerned about. In particular, it would be useful to examine the possible role of VAT design in affecting income inequality. While some works already explore the possible welfare effects of a broadening of the VAT base across different income groups (e.g., Mirrlees et al. (2011) and Netherlands Bureau for Economic Policy Analysis (2015)), it might be also fruitful to investigate the possible trade-off between efficiency and equity in the design of the VAT explicitly, including the use of differentiated rates. 


\section{Appendix A: Data sources}

The growth rate of annual real GDP per capita is calculated using per head real GDP in PPP terms available from the OECD. Tax revenue data at the general government level, including VAT revenue, are from the OECD Revenue Statistics Database. Total taxes are calculated from the database as the sum of consumption taxes (of which the VAT is a part), personal income taxes, corporate income taxes, property taxes, and social security contributions (which include taxes on payroll and workforce). To calculate the ratio of total taxes to GDP, nominal GDP from the OECD is used. A VAT standard rates dataset, which requires information on the month in which the rate was changed, is assembled using various sources, including the OECD, European Commission, IMF's Tax Policy Reform Database (Amaglobeli et al. 2018), and various official country documents. Final consumption expenditure in nominal terms (before VAT revenue is excluded), required to calculate $\mathrm{C}$-efficiency and the consumption ratio, is obtained from the OECD. Investment rate (gross fixed capital formation divided by GDP) is also from the OECD. While employment growth rate is calculated using the OECD data, when the AMECO database (European Commission) offers a longer time series for a country, we use this alternative data instead. Total government consumption, as the share of general government final consumption expenditure in GDP, is from the World Bank's World Development Indicators. Years of schooling (population aged 15-64), as a proxy for human capital, is from Barro and Lee (2013). Since this variable is available only every 5 years, it is interpolated accordingly.

\section{Appendix B: Unit root tests}

Table 7 shows results from two different panel unit root tests that allow for testing within unbalanced panels: the Maddala and Wu (1999) test and the Im et al. (2003) test. Both tests indicate that the null of non-stationarity is rejected for almost all the variables. (The VAT standard rate cannot be tested through the Im et al. (2003) test.) The only exception is that, as for human capital growth we consider as a part of the robustness check, the null is not rejected at the 10 percent level according to the Maddala and $\mathrm{Wu}$ (1999) test (p-value is 0.12), though it is rejected by the Im et al. (2003) test. 
Table 7 Panel unit root tests

\begin{tabular}{|c|c|c|}
\hline \multirow[t]{2}{*}{ Variable } & \multicolumn{2}{|c|}{ H0: panel contains unit roots } \\
\hline & Maddala and Wu (1999) & Im et al. (2003) \\
\hline \multirow[t]{2}{*}{ GDP p.c. growth rate } & $\chi(42): 260.82$ & t-bar: -11.51 \\
\hline & p-value: 0.00 & p-value: 0.00 \\
\hline \multirow[t]{2}{*}{ Total taxes/GDP } & $\chi(42): 95.23$ & t-bar: -3.45 \\
\hline & p-value: 0.00 & p-value: 0.00 \\
\hline \multirow[t]{2}{*}{ VAT/Total taxes } & $\chi(42): 68.77$ & t-bar: -1.80 \\
\hline & p-value: 0.01 & p-value: 0.04 \\
\hline \multirow[t]{2}{*}{ (Total taxes-VAT-Inc taxes)/Total taxes } & $\chi(42): 126.58$ & t-bar: -5.30 \\
\hline & p-value: 0.00 & p-value: 0.00 \\
\hline \multirow[t]{2}{*}{ (Total taxes-VAT-Pers inc taxes)/Total taxes } & $\chi(42): 105.76$ & t-bar: -3.18 \\
\hline & p-value: 0.00 & p-value: 0.00 \\
\hline \multirow[t]{2}{*}{ (Total taxes-VAT-Corp inc taxes)/Total taxes } & $\chi(42): 87.63$ & t-bar: -3.40 \\
\hline & p-value: 0.00 & p-value: 0.00 \\
\hline \multirow[t]{2}{*}{ C-efficiency $(\log )$} & $\chi(42): 88.32$ & t-bar: -3.83 \\
\hline & p-value: 0.00 & p-value: 0.00 \\
\hline \multirow[t]{2}{*}{ VAT standard rate $(\log )$} & $\chi(42): 84.84$ & t-bar: N/A \\
\hline & p-value: 0.00 & p-value: N/A \\
\hline \multirow[t]{2}{*}{ Consumption/Total taxes (log) } & $\chi(42): 60.15$ & t-bar: -1.49 \\
\hline & p-value: 0.03 & p-value: 0.07 \\
\hline \multirow[t]{2}{*}{ Investment rate } & $\chi(42): 90.57$ & t-bar: -4.33 \\
\hline & p-value: 0.00 & p-value: 0.00 \\
\hline \multirow[t]{2}{*}{ Employment growth } & $\chi(42): 238.82$ & t-bar: -10.77 \\
\hline & p-value: 0.00 & p-value: 0.00 \\
\hline \multirow[t]{2}{*}{ Government consumption } & $\chi(42): 96.56$ & t-bar: -4.01 \\
\hline & p-value: 0.00 & p-value: 0.00 \\
\hline \multirow[t]{2}{*}{ Human capital growth } & $\chi(42): 52.84$ & t-bar: -1.46 \\
\hline & p-value: 0.12 & p-value: 0.07 \\
\hline
\end{tabular}

Notes: 830 observations, 21 countries. The number of lags used is specified as 1 for both tests

\section{Appendix C: Cyclicality of tax compositions}

Figure 3 presents the correlation between the tax shares of the VAT and income taxes in total taxes (considering deviations from the national means) and the output gap. The respective OLS fitted lines suggest that while the VAT share does not show a statistically significant cyclical pattern, the income tax share shows a significant pro-cyclical pattern. 

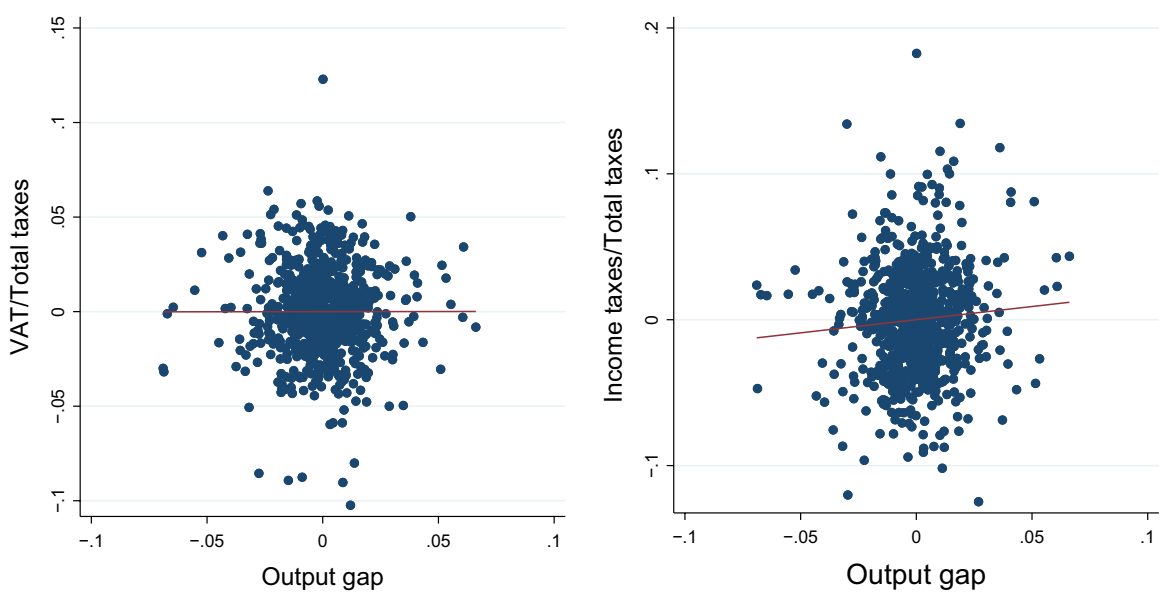

VAT/Total taxes: coef $=.001 ;$ (robust)se $=.036 ; \mathrm{t}=0.04$ Income taxes/Total taxes: coef $=.181 ;$ (robust)se $=.0498 ; \mathrm{t}=3.63$

Fig. 3 Cyclicality of tax composition. Notes: Both tax shares are deviations from respective national means. 830 observations from 21 countries are pooled. Clustered standard errors are used to adjust for correlation of error terms within countries

Acknowledgements We thank Andy Berg, Shun-ichiro Bessho, Michael Bleaney, Valerie Cerra, Hamid Davoodi, Norman Gemmell, Michael Keen, Junji Ueda, Francisco Veiga, two anonymous referees, and participants at seminars at IMF, Ministry of Finance, Japan, and University of Tokyo, and 76th annual congress of the IIPF for their comments. The conventional disclaimer applies.

Funding The authors have no relevant financial or non-financial interests to disclose.

Data availability The data that support the findings of this study are openly available in "figshare" at https://figshare.com/articles/dataset/VAT_design_and_growth/13007861.

\section{Declarations}

Conflicts of interest No conflicts of interest to disclose.

Open Access This article is licensed under a Creative Commons Attribution 4.0 International License, which permits use, sharing, adaptation, distribution and reproduction in any medium or format, as long as you give appropriate credit to the original author(s) and the source, provide a link to the Creative Commons licence, and indicate if changes were made. The images or other third party material in this article are included in the article's Creative Commons licence, unless indicated otherwise in a credit line to the material. If material is not included in the article's Creative Commons licence and your intended use is not permitted by statutory regulation or exceeds the permitted use, you will need to obtain permission directly from the copyright holder. To view a copy of this licence, visit http://creativecommons.org/licen ses/by/4.0/.

\section{References}

Acosta-Ormaechea, S., Sola, S., \& Yoo, J. (2019). Tax composition and growth: A broad cross-country perspective. German Economic Review, 20, e70-e106. 
Adhikari, B. (2020). Does a value-added tax increase economic efficiency? Economic Inquiry, 58, 496-517.

Aizenman, J., \& Jinjarak, Y. (2008). The collection efficiency of the value added Tax: Theory and international evidence. Journal of International Trade and Economic Development, 17, 391-410.

Alm, J., \& El-Ganainy, A. (2013). Value-added taxation and consumption. International Tax and Public Finance, 20, 105-128.

Amaglobeli, D., V. Crispolti, E. Dabla-Norris, P. Karnane, and F. Misch (2018): Tax policy measures in advanced and emerging economies: A novel database, IMF Working Paper 18/110.

Arnold, J. M., Brys, B., Heady, C., Johansson, Å., Schwellnus, C., \& Vartia, L. (2011). Tax policy for economic recovery and growth. Economic Journal, 121, F59-F80.

Barro, R., \& Lee, J.-W. (2013). A new data set of educational attainment in the world, 1950-2010. Journal of Development Economics, 104, 184-198.

Barro, R. and X. Sala-i Martin (2004): Economic Growth, Cambridge, Massachusetts: MIT Press, second ed.

Bettendorf, L. and S. Cnossen (2015): The long shadow of the European VAT, exemplified by the Dutch experience. FinanzArchiv: Public Finance Analysis, 71, 118-139.

Bleaney, M., Gemmell, N., \& Kneller, R. (2001). Testing the endogenous growth model: Public expenditure, taxation, and growth over the long run. Canadian Journal of Economics, 34, 36-57.

Cnossen, S., et al. (2010). Value Added Taxes and Excises: Commentary. In J. Mirrlees (Ed.), Dimensions of tax design: The Mirrlees Review (pp. 370-386). Oxford University Press for Institute for Fiscal Studies.

Cnossen, S. (2020). Modernizing the European VAT, CESifo Working Papers No. 8279.

Council VAT Directive (2006). Council Directive 2006/112/EC of 28 November 2006 on the common system of value added tax, https://eur-lex.europa.eu/eli/dir/2006/112/oj.

Crawford, I., Keen, M., \& Smith, S., et al. (2010). Value Added Taxes and Excises. In J. Mirrlees (Ed.), Dimensions of tax design: The Mirrlees Review (pp. 275-362). Oxford University Press for Institute for Fiscal Studies.

Dabla-Norris, E., \& Lima, F. (2018). Macroeconomic effects of tax rate and base changes: Evidence from fiscal consolidations, IMF Working Paper 18/220.

De Mello, L. (2009). Avoiding the value added tax: Theory and cross-country evidence. Public Finance Review, 37, 27-46.

Ebrill, L., Keen, M., Bodin, J.-P., \& Summers, V. (2001). The modern VAT. International Monetary Fund.

Elgin, C., \& Birinci, S. (2016). Growth and informality: A comprehensive panel data analysis. Journal of Applied Economics, 19, 271-292.

Ferede, E., \& Dahlby, B. (2012). The impact of tax cuts on economic growth: Evidence from the Canadian provinces. National Tax Journal, 65, 563-594.

Gemmell, N., Kneller, R., \& Sanz, I. (2011). The timing and persistence of fiscal policy impacts on growth: Evidence from OECD countries. Economic Journal, 121, F33-F58.

Gemmell, N., Kneller, R., \& Sanz, I. (2014). The growth effects of tax rates in the OECD. Canadian Journal of Economics, 47, 1217-1255.

Gemmell, N., Kneller, R., \& Sanz, I. (2016). Does the composition of government expenditure matter for long-run growth levels? Oxford Bulletin of Economics and Statistics, 78, 522-547.

Im, K. S., Pesaran, M. H., \& Shin, Y. (2003). Testing for unit roots in heterogeneous panels. Journal of Econometrics, 115, 53-74.

IMF. (2011). Revenue mobilization in developing countries. International Monetary Fund, Washington, D.C.: Policy Paper Series.

Institute for Fiscal Studies. (2011). A retrospective evaluation of elements of the EU VAT system, Taxation Studies 0039. European Commission: Directorate General Taxation and Customs Union.

Keen, M. (2013). The anatomy of the VAT. National Tax Journal, 66, 423-446.

Kneller, R., Bleaney, M. F., \& Gemmell, N. (1999). Fiscal policy and growth: Evidence from OECD countries. Journal of Public Economics, 74, 171-190.

Kneller, R. A. and F. Misch (2011): What does ex-post evidence tell us about the output effects of future tax reforms? ZEW Discussion Papers, No.11-029.

Lee, Y., \& Gordon, R. (2005). Tax structure and economic growth. Journal of Public Economics, 89, 1027-1043.

Loayza, N. V., \& Rancière, R. (2006). Financial development, financial fragility, and growth. Journal of Money, Credit and Banking, 38, 1051-1076. 
Maddala, G. and S. Wu (1999): "A comparative study of unit root tests with panel data and a new simple test," Oxford Bulletin of Economics and Statistics, Special Issue, 631-652.

Mendoza, E. G., Milesi-Ferretti, G. M., \& Asea, P. (1997). On the ineffectiveness of tax policy in altering long-run growth: Harberger's superneutrality conjecture. Journal of Public Economics, 66, 99-126.

Mirrlees, J., et al. (2011). Tax by design: The Mirrlees Review. Oxford University Press for Institute for Fiscal Studies.

Netherlands Bureau for Economic Policy Analysis. (2015). A study on the economic effects of the current VAT rates structure, Taxation Studies 0056. European Commission: Directorate General Taxation and Customs Union.

OECD. (2018). Consumption Tax Trends 2018, trends and policy issues. OECD Publishing, Paris,. https://doi.org/10.1787/ctt-2018-en.

Pesaran, M. H., Shin, Y., \& Smith, R. P. (1999). Pooled mean group estimation of dynamic heterogeneous panels. Journal of the American Statistical Association, 94, 621-34.

Pesaran, M. H., \& Smith, R. P. (1995). Estimating long-run relationships from dynamic heterogeneous panels. Journal of Econometrics, 68, 79-113.

Riera-Crichton, D., Vegh, C. A., \& Vuletin, G. (2016). Tax multipliers: Pitfalls in measurement and identification. Journal of Monetary Economics, 79, 30-48.

Sancak, C., J. Xing, and R. Velloso (2010): Tax revenue response to the business Cycle, IMF Working Paper 10/71.

Schneider, F. (2005). Shadow economies around the world: What do we really know? European Journal of Political Economy, 21, 598-642.

Smart, M., \& Bird, R. M. (2009). The impact on investment of replacing a retail sales tax with a valueadded tax: Evidence from Canadian experience. National Tax Journal, 62, 591-609.

Summers, L. H. (2014). U.S. economic prospects: Secular stagnation, hysteresis, and the zero lower bound. Business Economics, 49, 65-73.

Tanzi, V. (1999). Uses and abuses of estimates of the underground economy. Economic Journal, 109, F338-F347.

Tanzi, V. and H. Davoodi (2000): Corruption, growth, and public finances, IMF Working Paper 00/182.

Ueda, J. (2017): The evolution of potential VAT revenues and C-efficiency in advanced economies, IMF Working Paper.

Ufier, A. (2014). Quasi-experimental analysis on the effects of adoption of a value added tax. Economic Inquiry, 52, 1364-1379.

Xing, J. (2012). Tax structure and growth: How robust is the empirical evidence? Economics Letters, 117, $379-382$.

Publisher's Note Springer Nature remains neutral with regard to jurisdictional claims in published maps and institutional affiliations. 